\title{
A synthesis of the ecological processes influencing variation in life history and movement patterns of American eel: towards a global assessment
}

\author{
Luis A. Vélez-Espino · Marten A. Koops
}

Received: 25 April 2009/ Accepted: 30 July 2009/Published online: 12 August 2009

(C) The Author(s) 2009. This article is published with open access at Springerlink.com

\begin{abstract}
American eel, Anguilla rostrata, is a catadromous fish that spawns in the Sargasso Sea and migrates to coastal waters and freshwater systems ranging from Greenland down the Atlantic coast to South America and has been regarded as comprising a panmictic population. American eel is in decline across much of its range. Research and management is primarily conducted at local to regional scales, yielding inconsistent research results and management recommendations that may be inhibited by large-scale processes. We review the research on American eel ecology demonstrating that its variable life history and movement patterns can be explained based on: (1) latitudinal productivity gradients; (2) ideal free habitat selection; (3) conditional evolutionarily stable life history strategies; (4) size at arrival to the coast (correlated with distance from the spawning grounds); and, (5) temperature variance and annual degree-day effects on somatic growth. Using these ecological processes, we outline how local and large-
\end{abstract}

\section{A. Vélez-Espino · M. A. Koops}

Great Lakes Laboratory for Fisheries and Aquatic Sciences, Fisheries and Oceans Canada, 867 Lakeshore Road, Burlington, ON L7R 4A6, Canada

e-mail: Marten.Koops@dfo-mpo.gc.ca

L. A. Vélez-Espino ( $\bowtie)$

Pacific Biological Station, Fisheries and Oceans Canada, 3190 Hammond Bay Road, Nanaimo, BC V9T 6N7,

Canada

e-mail: Antonio.Velez-Espino@dfo-mpo.gc.ca scale effects on American eel dynamics can be integrated in a panmictic (or quasi-panmictic) modelling framework to enable defensible predictions of population responses to anthropogenic and oceanic phenomena. Due to its widespread distribution and existing knowledge gaps, the conservation and management of American eel will require international cooperation.

Keywords Eel · Panmixis - Catadromy · Population dynamics - Conditional strategies · Aquatic productivity $\cdot$ Sargasso Sea . Large marine ecosystems

\section{Introduction}

Among the Anguilla species inhabiting the Atlantic Ocean, American eel (Anguilla rostrata) is the only species of the genus found in eastern North American waters (Thibault et al. 2007b). The American eel exhibits unique population attributes: it seems to comprise a panmictic population (Williams and Koen 1984; Avise et al. 1986; Wirth and Bernatchez 2003); displays a geographical distribution with continental population segments ranging from southwestern Greenland (Tesch 1977; Boetius 1985) to the north coast of Venezuela (Tesch 1977; Penczak and Lasso 1991; FAO 2002); and, displays migratory patterns 
ranging from catadromy (hatched in the ocean with the growth phase of their life cycle in freshwater) to semi-catadromy where the growth phase takes place in salt and brackish continental waters (Haro and Krueger 1988; Jessop et al. 2002, 2006). Plasticity in diadromy has led some authors to categorize American eel as facultative catadromous (Daverat et al. 2006; Lamson et al. 2006; Thibault et al. 2007b). A variety of movement patterns and great phenotypic plasticity seem to be fundamental for the success of a panmictic species that is also characterized by a semelparous life history (Jessop et al. 2002).

Adult eel across the entire geographic range migrate from continental waters to the Sargasso Sea to reproduce and die, and their offspring disperse randomly during the larval stage (Avise et al. 1986; Wirth and Bernatchez 2003). Larvae (leptocephali) undergo a first metamorphosis and migrate into fresh, brackish and coastal waters as sexually undifferentiated juveniles (glass eel). After several years in these habitats, where eel develop into elver and then yellow eel, sexual differentiation takes place and adult eel undergo a second metamorphosis (silver eel) enabling them to migrate back to the spawning area (Tesch 2003).

In addition to the genetic evidence, highly skewed sex ratios of adult American eel (Oliveira et al. 2001) strengthen the case for panmixis since different proportions of males and females are produced in different regions and only a panmictic population or quasi-panmictic assemblage of populations would enable the viability and persistence of multiple locations exhibiting extreme effective population sizes or the absence of males (e.g., in Lake Ontario and the upper St. Lawrence River; Hurley 1972; Jessop 1987; Fournier and Caron 2005). Additional evidence of panmixis in American eel comes in the form of synchronous declines over portions of the species range (Richkus and Whalen 2000) and synchronous declines in glass eel size at arrival to the coast (Sullivan et al. 2006). The latter phenomenon takes place despite no significant synchrony in other important local processes such as the annual timing and abundance of glass eel at arrival to the coast (Sullivan et al. 2006).

Evidence compiled from commercial catch data, upstream passage counts, and seine, trawl and electrofishing surveys, indicates abundance declines in American eel across its North American range (Haro et al. 2000; Richkus and Whalen 2000; Casselman 2003). Critical gaps in scientific knowledge (Stone 2003) have prevented a thorough analysis of the population dynamics of this species and a confident separation of the relative effects of anthropogenic and natural sources of mortality. Similar declines (in magnitude and time period) observed in populations of European (A. anguilla) and Japanese (A. japonica) eel (Castonguay et al. 1994b; Moriarty and Dekker 1997; Stone 2003; Tatsukawa and Matsumiya 1999) suggest that global oceanic changes are similarly and simultaneously affecting these species (Knights 2003; Kimura and Tsukamoto 2006; Friedland et al. 2003), that human activities have exerted similar pressure on continental and marine life stages of all eels (Haro et al. 2000; Feunteun 2002; Dekker 2003), or that both factors may be involved. For instance, declines in the size of glass American eel arriving to the coastal United States (Sullivan et al. 2006), which might negatively influence first year survival (Sogard 1997), could be an important indicator of oceanic environmental factors operating at large geographic scales.

The existence of American eel and other Anguilla species in temperate regions is believed to be the result of a range expansion and evolution from tropical species that exhibit the typical catadromous life cycle (Tsukamoto et al. 2002). Arguably, existing evidence supports the hypothesis that eels evolved a migratory behaviour in response to the relative habitat productivity prevailing in their geographical range (Edeline 2007) — temperate eels living at higher latitudes with higher oceanic productivity exhibit a greater probability of remaining in lower reaches in brackish water than eels living at lower latitudes (Daverat et al. 2006) with higher freshwater productivity. But other factors must be involved since general patterns defining the variation in life history traits and movement patterns as functions of latitude (Helfman et al. 1987; Tesch 2003) or ocean-freshwater productivity gradients (Jessop et al. 2004) show some inconsistencies across the entire geographical range of the species (e.g., Hansen and Eversole 1984; Krueger and Oliveira 1999; Oliveira et al. 2001). Since panmixis would preclude the segregation of genotypes, local differences in life history patterns would be most likely phenotypic in origin (Jessop et al. 2004) and triggered by biotic and abiotic factors associated with local habitats.

The primary objective of this paper is to present a synthesis of ecological processes that explain life 
history and movement patterns across this species distribution, hence providing a foundation for the analysis of the population dynamics of American eel. Although current evidence advocates for a panmictic population, throughout this paper we also consider the possibility of future research indicating spatial or temporal segregation of American eel subpopulations resembling quasi-panmictic or metapopulation dynamics (see De Leo et al. 2009). We also discuss how recognizing large-scale processes can assist modelling population dynamics and inform management decisions. We argue that an initial approach to a global assessment should be based on life history data and consider the dynamics of an unimpacted population. In this paper we identify the pressing need to develop biological models, following panmictic or quasi-panmictic approaches, on which the effects of various anthropogenic stressors could be analyzed afterwards to inform management based on the relative contributions of local stocks and their exploitation or perturbation rates.

\section{The limitation of local assessments}

American eel life history makes the construction of population models at the watershed or basin scale difficult as there are no reasons to expect a relationship between the local abundances of spawners and recruits. Under panmixis, the number of young eels entering a given river in a given year will not be related to the number of adults that left that river, but to the total number from all geographic areas combined that reached the spawning area in the Sargasso Sea (Castonguay et al. 1994a). This disassociation in the stock-recruitment relationship at the local scale will also hold for a quasi-panmictic assemblage of local populations between which differentiation is minimal and only weakly oriented to distance of geographic separation (see Avise and Felley 1979). The inappropriateness of a watershedbased stock-recruitment relationship for American eel suggests that both exploitation and conservation targets need to be set on the basis of panmictic or quasi-panmictic models, or a global assessment of metapopulation dynamics (De Leo et al. 2009). Nonetheless, some predictions derived from local stock-recruitment models could be consistent with the precautionary approach (FAO 1996; Richards and
Maguire 1998) when they result in reductions in fishing mortality, as stated by Russell and Potter (2003) regarding management of European eel. Insights from stock-recruitment models applied to arguably non-panmictic populations of European eel (Avise et al. 1986) could be more representative of its actual population dynamics than those produced for American eel. Yet, we argue that the lack of insight into population dynamics and the absence of plausible, ecologically sensitive, management solutions will remain without a panmictic (or quasi-panmictic) approach for American eel. A global modelling approach is a necessary tool to assess the effect of anthropogenic activities on American eel. However, its development has posed a pressing challenge.

\section{General patterns}

Field studies suggest that American eel life history traits such as longevity, growth rate, sex ratio, and age and size at maturity vary with latitude. (Helfman et al. 1987; Krueger and Oliveira 1999; Tesch 2003; see Fig. 1 for a summary of general patterns). Empirical data show that the proportion of males increases at lower latitudes (Helfman et al. 1984), and a latitudinal cline in somatic growth rates (faster growth in southern latitudes) irrespective of sex (Hansen and Eversole 1984; Oliveira 1999), but also show that size at maturity increases with latitude in females but not in males (Helfman et al. 1987; Oliveira 1999). These general patterns, also observed in European eel reproducing in the Sargasso Sea (Moriarty and Dekker 1997), support the hypothesis that silver eel metamorphosis and emigration are more dependent on sex-specific length than age (Helfman et al. 1987; Morrison and Secor 2003; De Leo and Gatto 1996). In addition, it has been demonstrated that somatic growth in temperate regions is faster in estuarine brackish environments than in either freshwater rivers or lakes (Thibault et al. 2007b), and that brackish water and saltwater residency in estuarine and coastal environments increases with latitude relative to other life history strategies (Daverat et al. 2006).

Female eel become sexually mature at larger sizes and older ages than males from a particular region (Helfman et al. 1987; Oliveira 1999; Oliveira and 
Fig. 1 General patterns between life history traits and population and geographic attributes in American eel. For simplicity, general patterns are represented linearly. See text for details
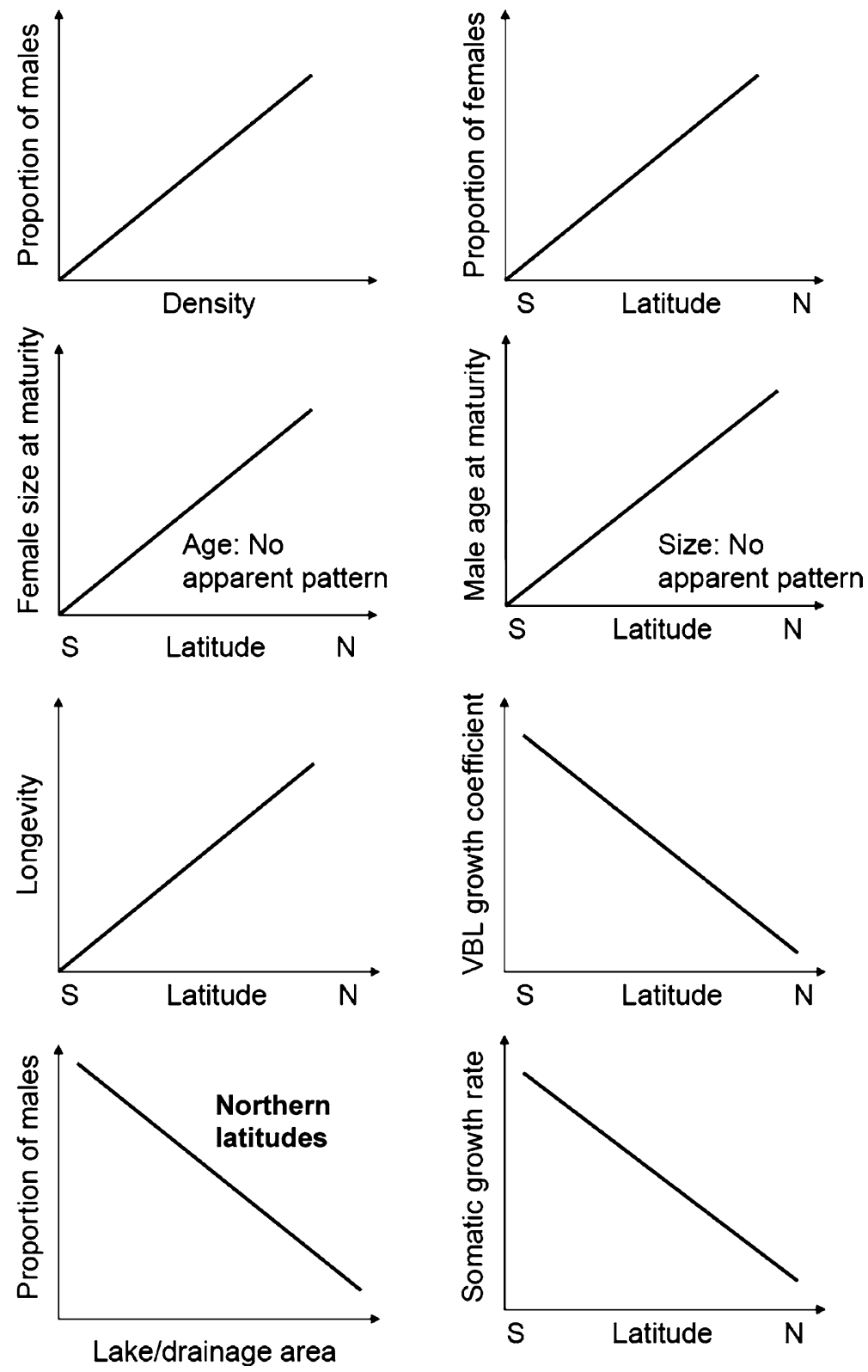

McCleave 2002) and, as a result, male size at seaward migration is significantly smaller than female size (Jessop et al. 2004). Males also approach their theoretical maximum length more quickly than females (Jessop et al. 2004), reflecting a negative relationship between growth rate and age at maturity consistent with life history theory (Stearns and Crandall 1984) and generally observed in eels (Vollestad 1992; Jellyman 2001; Oliveira and McCleave 2002).
The evidence from temperate regions

In addition to latitudinal gradients in life history traits and population attributes, there is a saltwater-freshwater gradient underpinning biological characteristics of American eel. Differences in life history traits within a watershed seem to be the result of movement patterns rather than movement patterns resulting from biological differences (Morrison et al. 2003; Thibault et al. 2007b; see Fig. 2 for a summary of patterns in 
Fig. 2 General relationships between life history traits and population attributes and a freshwater (FW), seawater (SW) gradient (or alternatively distance from the ocean) in temperate regions. For simplicity, general patterns are represented linearly, except density for which additional information is available. The relationship between distance from the ocean and mortality refers to the associated cost of migration

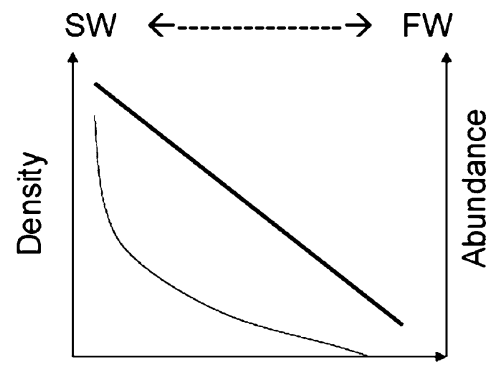

Distance from the ocean
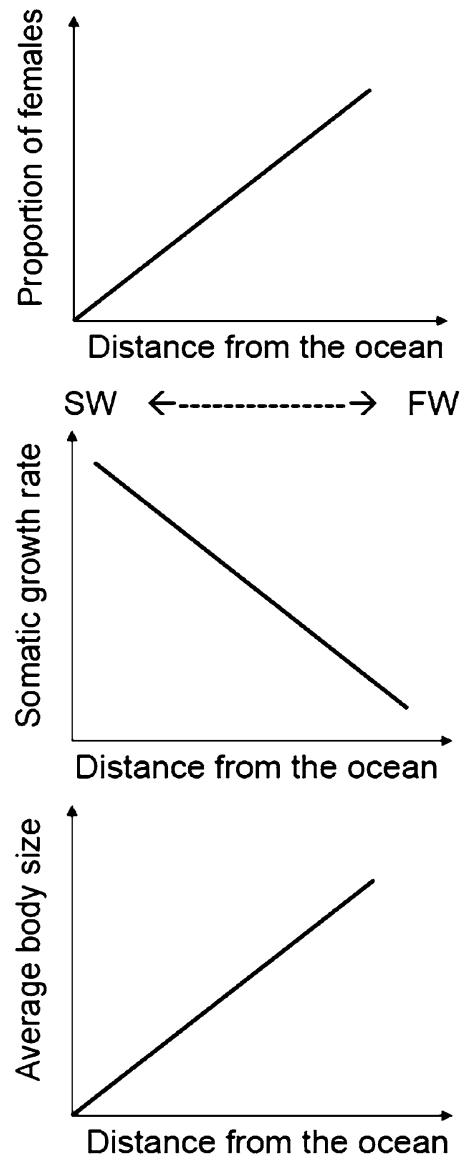

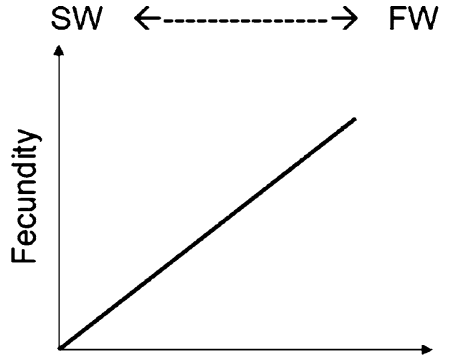

Distance from the ocean
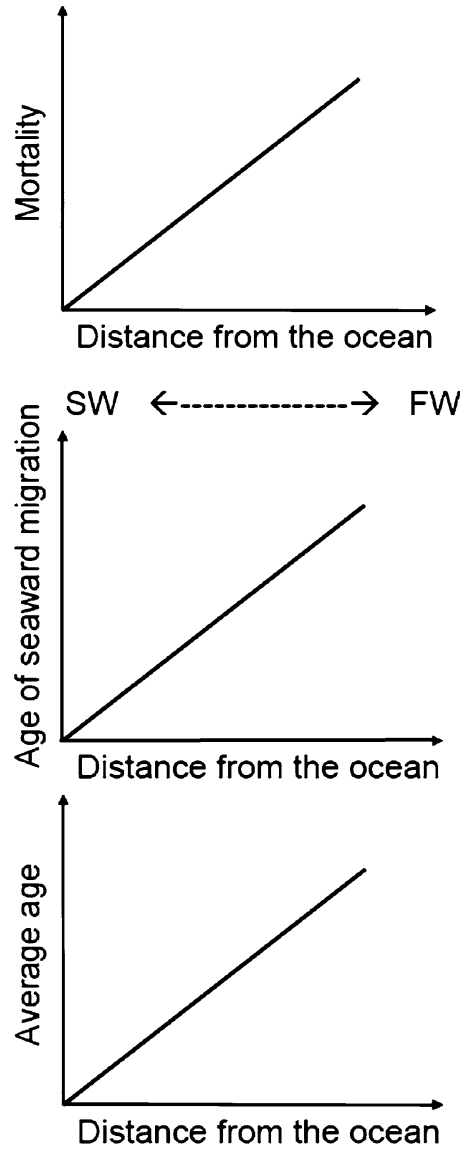

temperate latitudes). Habitats with similar environments produce eel with similar life histories (Oliveira and McCleave 2000), and the expression of different movement patterns between different aquatic environments and within a basin seems to be directly related to density in continental waters, distance from the spawning area, and drainage area. Field studies of American eel in continental habitats (elvers, yellows and silvers) at temperate latitudes suggest that inland distance from the ocean is an important correlate of variation in life history traits and population attributes. Overall, there is a clear pattern of more rapid somatic growth in estuarine than freshwater habitats at temperate latitudes (Helfman et al. 1984).

Smogor et al. (1995) found that a negative exponential diffusion model adequately described eel-density changes with distance from the ocean at large spatial scales such as physiographic province and drainage. The same kind of population diffusion process in relation to inland distance from the ocean has been described for European eel (Ibbotson et al. 2002). In many instances, this trend is not systematic 
Fig. 3 Inconsistencies in the general patterns in Figs. 1 and 2 across freshwater $(\mathrm{FW})$, seawater (SW) gradients; mainly documented for subpopulations in the southern range. See text for details
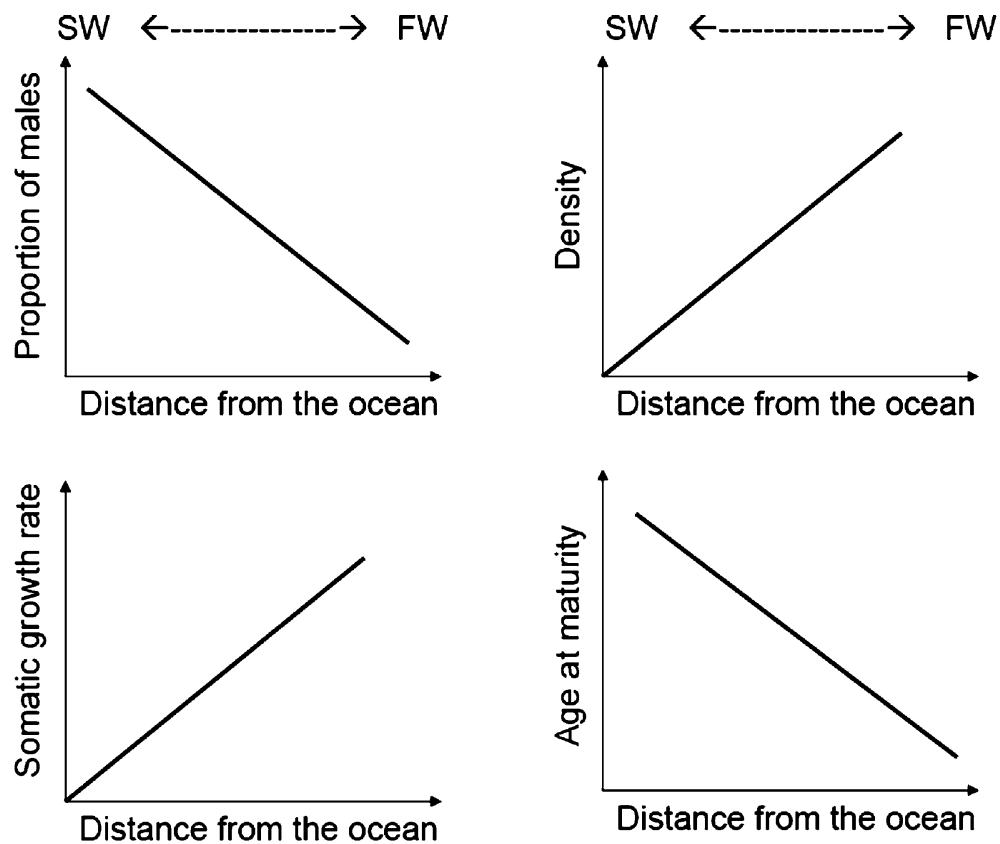

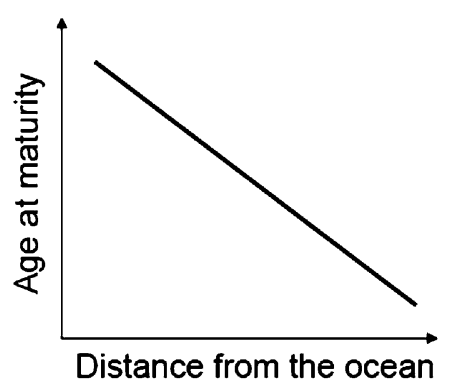

in short rivers where shifts between freshwater and brackish water occur frequently (Laffaille et al. 2003). This shifting pattern disappears when eel move further inland and settle at long distances from the ocean. For example, all freshwater American eel found $200 \mathrm{~km}$ from the river mouth in the Hudson River spent their entire yellow growth phase in freshwater (Morrison et al. 2003). Similar results have been found for European eel (Daverat and Tomás 2006).

The role of density in determining sex seems to be important, with high densities suppressing femaleness and strongly favouring male-biased sex ratios (Krueger and Oliveira 1999). An early hypothesis relating salinity to sex ratios in American eel, and associating females with freshwater and males with brackish and saltwater (e.g., Dolan and Power 1977), currently lacks empirical support. However, density is not the only factor to be strongly associated with the relative proportion of males and females (Krueger and Oliveira 1999; Oliveira and McCleave 2000; Tesch 2003). High male densities in coastal habitats are more evident in temperate latitudes (Vladykov 1966; Helfman et al. 1987; Krueger and Oliveira 1999). The proportion of males has been found to be inversely related to the amount of lacustrine habitat within temperate drainages (Oliveira et al. 2001), a relationship that may be influenced by the relative productivity of lacustrine and riverine environments (see below section on "Aquatic productivity").

The inconsistencies

Exceptions to the above patterns are represented by higher proportions of males reported in northern subpopulations (e.g., Vladykov 1966; Krueger and Oliveira 1997; Jessop et al. 2006) including freshwater systems (Facey and Helfman 1985; Krueger and Oliveira 1999), high variation in sex ratios over small geographic areas (e.g., Krueger and Oliveira 1999; Oliveira et al. 2001), predominance of males in freshwater habitats (e.g., Winn et al. 1975; Naismith and Knights 1990), and female predominance in brackish water (e.g., Hansen and Eversole 1984; Naismith and Knights 1990; see Fig. 3 for a summary of these relationships). Male dominated rivers have been also found at mid-Atlantic latitudes (Krueger and Oliveira 1997) suggesting that sex ratios may not be an exclusive function of latitudinal clines (Oliveira et al. 2001).

Although, on average, growth rates of yellow and silver female eel are higher than males (Oliveira 1999; Oliveira and McCleave 2002; Tzeng et al. 2003; Jessop et al. 2004), some studies have found higher growth rates for males than females (Poole and Reynolds 1996; Holmgren et al. 1997). One potential 
reason for this inconsistency may be an inability to accurately determine sex in young eel. Most sexspecific evaluations of early growth have been conducted indirectly through back-calculation from otolith increments. In addition, larger female size does not necessarily mean higher growth rates but could result from a longer lifespan and later age at maturity. Several studies have shown that high somatic growth rates during the first years of continental growth produce mostly males (Holmgren and Mosegaard 1996; Davey and Jellyman 2005). Increasing sex-specific divergence in somatic growth rates with age (e.g., Oliveira and McCleave 2002) has been associated with only female American eel achieving sizes enabling picivory (Krueger and Oliveira 1997; Oliveira and McCleave 2000) with higher yellow and silver growth rates than males exhibiting a generalist feeding behaviour (Helfman et al. 1987).

Although somatic growth in temperate regions is generally higher in brackish than freshwater habitats (Harrel and Locayano 1982; Hansen and Eversole 1984; Morrison and Secor 2003), an exception to this pattern occurs in Newfoundland where freshwater growth is slightly greater than in brackish and coastal waters (Gray and Andrews 1971). Similarly, Tzeng et al. (2003) observed higher estuarine growth in eel inhabiting semi-tropical regions, where freshwater systems are generally more productive than estuaries. Further, there are reports of growth rates of American eel inhabiting brackish waters in South Carolina being greater than those growing in brackish waters in the northern United States and Canada (Hansen and Eversole 1984). Although there is a significant correlation between latitude and age at seaward migration for both sexes, there is no relationship between size and latitude for male eel (Oliveira 1999).

\section{The synthesis}

Several studies have demonstrated that somatic growth rates of eels are mainly influenced by aquatic productivity, seasonal water temperatures, and duration of the growing season, all of which vary with latitude (Tesch 1977; Vollestad 1992; Jessop 1998). In addition, several studies assert that density alone explains the variation in sex ratio across the geographical range (e.g., Krueger and Oliveira 1999; Oliveira and McCleave 2000; Tesch 2003). Meanwhile, American eel densities are poorly or not correlated with habitat variables such as stream width, depth, substrate or flow (Huish and Pardue 1978; Smogor et al. 1995; Wiley et al. 2004). The same lack of association between physical habitat and densities has been reported for European eel (Feunteun et al. 1998). Our review of the literature indicates that the perception of ecological processes deemed important in explaining observed patterns changes with the scale of study (see also Morris 1987) and it remains a challenge to synthesise the ecological processes underpinning not only variation in somatic growth and sex ratio but other relevant life history traits and movement patterns of American eel across their range.

Analyzing eel life history and migration patterns at the scale of the entire geographical range reveals that the primary factors determining variation in life history traits and movement patterns are: (1) productivity gradients; (2) habitat selection following an ideal free distribution; (3) conditional evolutionarily stable life history strategies (ESS); (4) size at arrival to the coast; and, (5) temperature variance and annual degree-day effects on somatic growth. Although none of these factors solely explains the variety and plasticity of observed patterns, their interaction accounts for some apparent inconsistencies and explains large-scale regional patterns. We now detail how each of these ecological processes contribute to explaining observed behavioural and life history differences exhibited by American eel from different locations throughout their life cycle.

\section{Aquatic productivity}

Two dimensions of productivity gradients seem to be important factors influencing growth rates, age and size at maturity, and densities of American eel: (1) a latitudinal gradient in the ocean; and, (2) a saltwaterfreshwater gradient nested within the latitudinal gradient. The migration of American eel leptocephali to continental waters has been evolutionarily advantageous given the low nutrient content of the Sargasso Sea and its isolation from deep, nutrient rich cold waters (USFWS 2000). Migration patterns of American eel and many other fishes between freshwater and marine systems (diadromy) seem to primarily be 
a response to global patterns in aquatic productivity (Edeline 2007). Overall, higher oceanic productivity in temperate latitudes and higher freshwater productivity in tropical latitudes favour the evolution of anadromy (species spawned in freshwater with growth in the ocean) in temperate latitudes, and catadromy in tropical latitudes (Gross et al. 1988).

As a result of habitat suitability being partly defined by productivity gradients, marine and estuarine residence should occur more frequently at higher latitudes (Jessop et al. 2004), and higher densities could be supported in marine and estuarine habitats at high latitudes (see also Tsukamoto and Arai 2001) and in freshwater habitats in low latitudes. For example, differences in aquatic productivity along the Atlantic coast of Canada can be an order of magnitude higher in brackish estuaries than adjacent freshwater systems (Gagnon 2002). The ubiquitous evidence pointing to density as the primary determinant of sex in American eel (Krueger and Oliveira 1999; Oliveira and McCleave 2000; Tesch 2003) is only an indication of the role that aquatic productivity has on habitat selection, growth rates, and the subsequent gender determination resulting from fast early life growth (Mittwoch 1996; Davey and Jellyman 2005). Evidence indicates that slow growth prior to sexual differentiation favours the production of females in European eel (Holmgren and Mosegaard 1996; Holmgren et al. 1997). Thus, density will be correlated with sex ratio as long as density is correlated with productivity. High densities without high habitat productivity, and without the opportunity to move to lower density habitats (e.g., an isolated pond), will only produce stunted individuals (e.g., Paulovits and Viró 1986) and will not produce the high early life growth rates during the freshwaterbrackish phase deemed necessary for the production of males (Holmgren and Mosegaard 1996) or the larger individuals (generally females) found in less dense habitats (Davey and Jellyman 2005).

An inverse relationship between the proportion of males and the amount of lacustrine habitat, independent of upstream distance (Oliveira et al. 2001), also reveals the influence of aquatic productivity on both somatic growth and density at high latitudes. A greater proportion of lacustrine habitat relative to the drainage area translates into lower overall productivity because lakes are less productive than rivers (Randall et al. 1995) and low growth rates early in life favour the production of females (Holmgren and Mosegaard 1996; Holmgren et al. 1997).

Ideal free distribution

Movement patterns of American eel can be explained by a trade-off between residence in the most productive habitats and shifts to less productive lower-density habitats (Edeline 2007). Highly productive aquatic habitats constitute optimal habitats for somatic growth and usually harbour high densities. As individuals of a given species saturate this optimal habitat, overcrowding reduces habitat quality. Over-crowding in eels increases cannibalistic behaviour (Moriarty 1987; Edeline et al. 2005) and density-dependent mortality (Vollestad and Jonsson 1988), promoting the movement of individuals to less suitable habitats. Higher aquatic productivity in temperate latitudes induces higher growth rates and higher incidences of cannibalism in estuaries and saltwater than freshwater habitats (Edeline et al. 2005).

The ideal free distribution model of habitat selection (Fretwell and Lucas 1970) predicts equal fitness for both optimal and sub-optimal habitats because individual fitness increases at lower densities in sub-optimal habitats. At low density, an individual can achieve the highest fitness by selecting the most productive habitat. At high density an individual can select the most productive habitat under crowded conditions or less productive habitat under less crowded conditions. American eel remaining at high densities in highly productive habitat and those moving to less productive habitats achieve similar fitness through life history trade-offs. In females, there is a clearly defined trade-off between survival and fecundity (Davey and Jellyman 2005). As a result of the ideal free distribution, estuarine American eel in temperate latitudes grow faster than freshwater individuals, but size and age at maturity is lower and shorter in estuaries than freshwater systems (e.g., Helfman et al. 1984).

\section{Conditional ESS}

The American eel has evolved growth strategies that enable successful adaptation to a wide range of habitats (Oliveira and McCleave 2002). The potential for genetic influences on sex determination seems to 
be overridden by environmental factors (Tesch 2003) with environmental sex determination in American eel (Krueger and Oliveira 1997, 1999). This is consistent with the random dispersal of larvae transported by currents and tides, and the evolution of environmental sex determination when progeny cannot choose their environment (Charnov and Bull 1977). Sex-specific life history strategies may have evolved as adaptations to spatially heterogeneous continental habitats. To cope with conflicting selective pressures from heterogeneous and unpredictable environments, Anguilla eels seem to exhibit a conditional evolutionarily stable strategy (ESS; Edeline 2007). This conditional ESS must not be confused with a conditional strategy associated with alternative reproductive tactics within sexes where the fitness of alternative phenotypes is unequal (Gross 1996). American eel conditional ESS can be defined by a series of trade-offs specific to each sex.

Since mature males are significantly smaller than females (Krueger and Oliveira 1997) and females take longer to mature than males (Oliveira 1999; Oliveira and McCleave 2000), there is a bimodal size-distribution of migrating silver eel (Davey and Jellyman 2005). Eel exhibit sex-specific life-history strategies, with males growing faster than females during their early years but females reaching greater age and size at maturity and size at yellow-silver metamorphosis. The male strategy consists of maturing at the smallest size for a successful spawning migration (time-minimizing and growth maximizing strategy); whereas, the female strategy consists of maximizing size at maturity (size-maximizing strategy) where the fundamental trade-off in females is between survival to maturity and fecundity (Davey and Jellyman 2005). Although there would be a mortality cost associated with long-range inland migrations (Fig. 2), freshwater residency (at least in temperate latitudes) results in lower mortality rates compared to marine environments (Jonsson and Jonsson 1993). Lower survivorship from larvae to the time of seaward migration is expected in freshwater environments as a result later age at maturity. The trade-off for males is to compensate for increased mortality with faster somatic growth (Pauly 1980; Holmgren 1996; Wootton 1992) achieving increased survivorship to maturity by earlier maturation. As a result of these conditional strategies, size at maturity in males is less variable than age at maturity
(Tesch 2003) and silver males exhibit similar sizes across the geographic range (see Helfman et al. 1987; Oliveira 1999). Even males with different habitat residencies do not differ significantly in length at the time of seaward migration within regions (Jessop et al. 2004). Generally, the fertility of males does not depend on adult size but on the mating system; if mating occurs at random, size is not an important factor for male fertility, contrary to females where fecundity is proportional to body size (Mittwoch 1996). Based on direct observations, van Ginneken et al. (2005) concluded that induced spawning of European eel occurs collectively and simultaneously, possibly triggered by pheromones.

A demographic aspect of a conditional strategy that has not been noted is that shorter generation times in males (up to 4 years shorter; Oliveira and McCleave 2000) than females balances the overall female-biased sex ratio observed in continental eel stages at some locations. Higher frequencies of males migrating to the spawning area partially negate this bias for the spawning portion of the population according to the following relationship:

$f_{M}=\frac{P_{M} G_{M}^{-1}}{P_{M} G_{M}^{-1}+P_{F} G_{F}^{-1}}$

where $f_{M}$ is the frequency of males in the spawning area, $P_{M}$ and $P_{F}$ are the proportions of males and females in continental waters, respectively, and $G_{M}$ and $G_{F}$ are the generation times for males and females, respectively. Thus, a scenario with a continental sex ratio of $70 \%$ female and generation times of 5 and 10 years for males and females, respectively, produces a spawning area sex ratio of $54 \%$ females, substantially reducing the bias observed in continental waters.

Similarly, earlier age at maturity and age at seaward migration in males will reduce overall mortality following arrival at the coast, and this process will contribute to higher numbers of males in the spawning areas than expected for males maturing at the female age. Sex ratio is important in population dynamics because it influences variance in reproductive success (Nunney 1993) and a disparate sex ratio has a significant effect on the ability of a population to increase from low numbers. This ability is enhanced when females predominate and is depressed when males dominate (Caughley 1994). 
Size at arrival to the coast

Dispersal of leptocephali from the spawning area to coastal habitats occurs largely by passive drift (Kleckner and McCleave 1985). The mean total length of American eel leptocephali in collections associated with the Gulf Stream increases from south to north (Kleckner and McCleave 1982) without including tropical subpopulations. Larvae settling in continental areas farther from the Sargasso Sea are older and exhibit larger body size after spending more time drifting with oceanic currents prior to arriving at the coast (e.g., Haro and Krueger 1988; Sullivan et al. 2006). As body size increases in fishes, swimming ability increases and the relative cost of swimming decreases (Ware 1982; Helfman et al. 1997). The ability of eels to colonize freshwater habitats has been associated with high locomotor activity (Edeline et al. 2005). Higher energetic status would enable American eel at the extremes of its range to undertake inland migrations and gain fitness by inhabiting low-density river habitats (see also Edeline 2007) or by reaching habitats with optimal suitability. High energetic status could explain the high proportion of eel migrating to freshwater habitat as elvers in the East River, Nova Scotia (Jessop et al. 2006) and their capacity to undertake the long migration to Lake Ontario (Busch et al. 1998). Long-distance inland movements comparable to those enabling the presence of American eel in Lake Ontario have not been reported in the southern extreme of the distribution (e.g., Penczak and Lasso 1991; FAO 2002). However, American eel have been found in underground freshwater systems more than $50 \mathrm{~km}$ from the coast in the Yucatan Peninsula, in Mexico (Iliffe 1993). Longer inland migrations in tropical latitudes might not be necessary since high productivities can be encountered in downstream reaches from both cumulative allochthonous and high autochthonous production (Lowe-McConnell 1987; Benke et al. 1988) and lower densities of glass eels (Kleckner and McCleave 1982) reduce the propensity to migrate.

\section{Temperature}

Latitudinal increases in water temperature, degreedays, and the duration of the growing season from north to south have been associated with changes in life history traits such as growth, mortality, and longevity (Beamesderfer and North 1995; LobónCerbiá et al. 1996; Braaten and Guy 2002). Studies of European eel have shown that, although differentiation of the gonads takes place during the yellow stage (Colombo and Grandi 1996), the growth rate of elvers during their first year of life emerges as a strong predictor of subsequent gender with males growing faster than females in the early stages (Holmgren et al. 1997). Sex determination occurring early in life is also supported by the lack of evidence for sex reversal in mature eel (Servidio 1986; Krueger and Oliveira 1999). Feeding and growth are almost nil during the cold season in temperate latitudes (Walsh et al. 1983) and, although growth has been positively correlated with water temperature (Holmgren 1996), existing evidence has failed to explain variation in growth solely as a function of annual temperatures (Krueger and Oliveira 1999; Oliveira et al. 2001).

Temperature also fails to explain the variability in sex ratios within regions subject to similar annual temperature ranges (Krueger and Oliveira 1999; Oliveira et al. 2001). Davey and Jellyman (2005) suggested that high productivity and high temperatures should result in a greater proportion of males. We suggest that faster growth during the elver stage would not be directly related to average annual temperatures but rather to productive habitats with lower temperature variance (less seasonality) and greater degree-days per year. This would partly explain the overall low proportion of males in brackish and coastal waters in northern latitudes, and the increase in the proportion of males in estuarine systems as latitude decreases and in freshwater systems at tropical latitudes. Despite some studies suggesting that fishes in northern latitudes can experience higher growth rates during their first growing season than fishes in southern latitudes, offsetting the shorter duration of the growing season at high latitudes (Arendt 1997; Connover et al. 1997), this latitudinal compensation is not obvious in American eel probably as a result of panmixis (Oliveira 1999). The combination of high habitat productivity, low temperature variance, and high degree-days in tropical freshwater systems predicts a higher proportion of males at lower latitudes. Large size at arrival to the coast, high oceanic productivity, an ideal free distribution of habitat selection, and a conditional ESS strategy favouring the maximization 
of female size explain the quasi-absolute femaleness of American eel and their largest size reported anywhere in the upper St. Lawrence and Lake Ontario (Verreault et al. 2003).

Some reports indicating extreme male-biased sex ratios of yellow or silver eel in temperate rivers (e.g., Oliveira 1999; Oliveira et al. 2001) are inconclusive since these reports classified eel as male or female based solely on size (Krueger and Oliveira 1997; Oliveira and McCleave 2000). However, male-biased sex ratios have been found in temperate rivers when sex was determined through gonad examination (e.g., Krueger and Oliveira 1999). These apparent inconsistencies have been reported for freshwater systems near coastal waters and, generally, less than $20 \mathrm{~km}$ from the ocean. There are no reports of male-biased sex ratios in temperate freshwater systems more than $50 \mathrm{~km}$ from the ocean. This may indicate that aquatic productivity and other elements of habitat suitability, such as distance from the ocean and fish assemblages (e.g., Wiley et al. 2004) as well as lower temperature variance in more protected habitats, interact to determine overall eel density and propensity for male production. Chiefly, males are expected to be more common, without being predominant, at lower latitudes (Helfman et al. 1984).

\section{Modelling American eel dynamics}

A starting point: a global biological model

The management of American eel at a global scale has been a persistent idea because of the panmictic (or quasi-panmictic) nature of the species (Castonguay et al. 1994a; Haro et al. 2000; Casselman 2003; De Leo et al. 2009). While site-specific analyses are needed to understand eel life history in the continental phase, the study of the generalized decline of American eel recruitment requires a global assessment (De Leo et al. 2009). In addition, the paucity and incompleteness of historical data on eel abundance, stock structure, life stage mortality rates, abundance trends, and exploitation rates, pose great obstacles to investigating the potential influence of these factors even on regional scales (Haro et al. 2000). Standard fisheries models using local population data face serious limitations for the study of American eel (BII 2001; EPRI 1999) particularly when these models are populated with commercial data.

Among the characteristics that make American eel life history unconventional (Haro et al. 2000), panmixis (or quasi-panmixis) should be, without doubt, a fundamental basis for population models attempting to predict the effects of human activities on recruitment (Castonguay et al. 1994a). An important limitation to the development of a panmictic model has been a lack of knowledge about the number of spawning eel in any year (Stone 2003) because, in part, the exact location of spawning within the Sargasso Sea is still unknown (McCleave 1993; ASMFC 2000). The construction of such a model would therefore require: (1) defining subpopulations across the geographic range including at the extremes of the geographic distribution; (2) the integration of various migratory patterns observed in American eel; (3) estimates of the likelihood of occurrence across the range; and, (4) the development of functional relationships that can fill information gaps in eel life history. The development of functional relationships should be based on models relating the five ecological processes highlighted in the previous section ("The Synthesis") with observed variation in life history traits and movement patterns of American eel. This exercise may benefit from data on other Anguilla species exhibiting similar life history strategies (Haro et al. 2000).

Defining subpopulations

An ecosystem-based approach can be used to define American eel subpopulations. On a global scale, 50 large marine ecosystems (LME) produce most (8095\%) of the marine fishery biomass yield (Sherman 1994; Duda and Sherman 2002; see Fig. 4). These LME are regions of ocean space $\left(\sim 200,000 \mathrm{~km}^{2}\right)$ encompassing coastal areas from river basins and estuaries out to the seaward boundaries of continental shelves and the outer margins of coastal current systems characterized by distinct bathymetry, hydrography, productivity, and trophically dependent populations (Sherman and Duda 1999; Duda and Sherman 2002). Due to the role that environmental factors have in the life history and movement patterns of American eel, the factors characterizing each LME will be important determinants of the likelihood of occurrence of American eel subpopulations with 
Fig. 4 Large Marine Ecosystems (LME) of the world. The polygon encompasses the seven LME (Gulf of Mexico [5], Southeast US continental shelf [6], Northeast US continental shelf [7], Scotian shelf [8], Newfoundland-Labrador shelf [9], West Greenland shelf [10], Caribbean Sea [12]) with occurrences of American eel across the entire species range. Redrawn with permission from Sherman and Duda (1999)

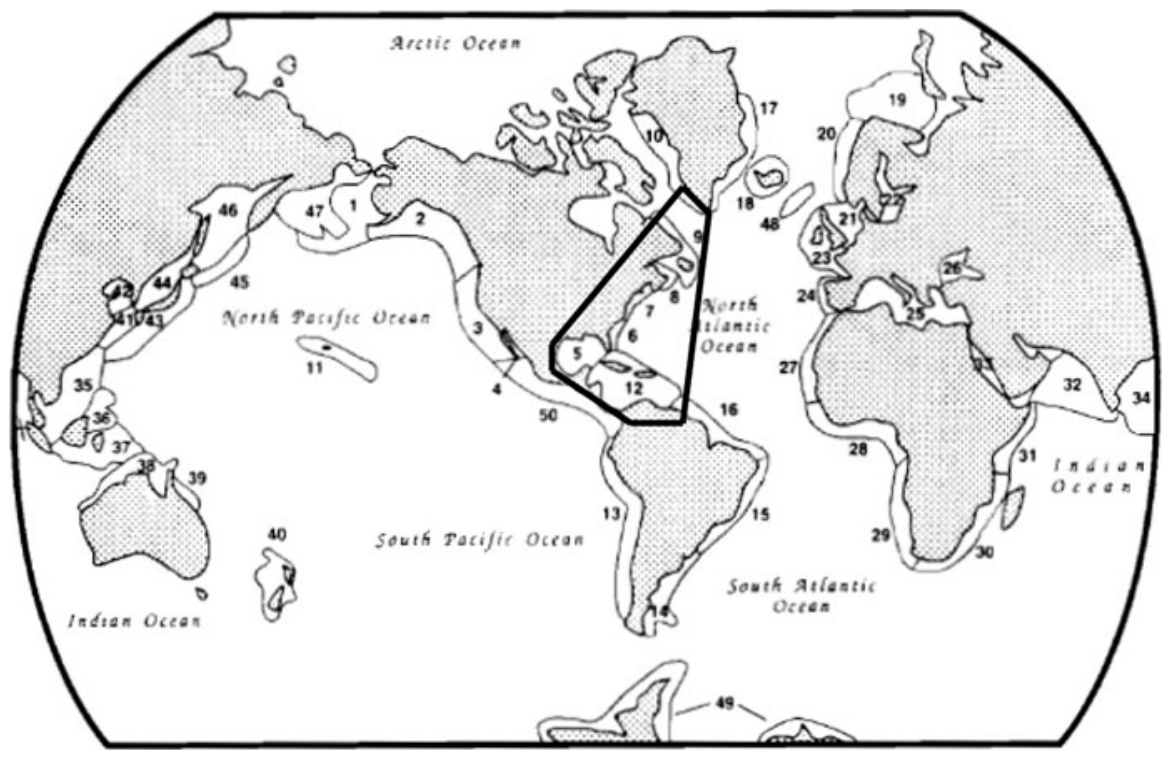

distinct demographic characteristics. In addition, LMEs represent national and regional focal areas of a global effort to reduce the degradation of linked watersheds, marine resources and coastal environments from pollution, habitat loss and overfishing (Duda and Sherman 2002), thereby, providing appropriate population units for large-scale management actions. LMEs are suitable for evaluating different levels of response to naturally occurring environmental shifts in climate change and impacts such as changes in upwelling strength and displacement of oceanic currents (Duda and Sherman 2002), which is of crucial importance given the role of oceanic currents in transporting leptocephali to continental waters.

The paucity of information on subpopulation size and densities requires indirect ways of representing the relative demographic contributions of each subpopulation to the entire panmictic population. For example, large-scale predictions of the likelihood of occurrence of species that use marine environments are available. AquaMaps (developed by Kaschner et al. 2007) is an online resource linked to FishBase (http://fishbase. sinica.edu.tw/tools/aquamaps/receive.php) that constructs model-based maps of the likelihood of occurrence from estimates of the environmental tolerance of a given species with respect to depth, salinity, temperature, primary productivity, and its association with sea ice or coastal areas. Predictions are generated by matching habitat usage of species, termed environmental envelopes, against local environmental conditions to determine the relative suitability of specific geographic areas for a given species. There is a wide range of tools that can be used to predict species distributions based on occurrence records, ranging from simple environmental envelope models that only require information about where a species has been reported (presences) to more complex models that need both information about a species presence as well as where it has been reported to be absent (Guisan and Zimmermann 2000).

An AquaMap for American eel is available and could be used to replace subpopulation sizes or densities by a metric combining likelihood of occurrence of larvae in coastal regions and estimates of continental population size based on area of occurrence, drainage area or discharge (Castonguay et al. 1994a) for each subpopulation in a panmictic or quasi-panmictic model. The number of young eel recruiting to river systems has been estimated as a function of water discharge (COSEWIC 2006). This rationale could be extended to estimate recruitment at the subpopulation level. Lower likelihoods of occurrence in southern locations, as depicted in the American eel AquaMap (figure not shown), is consistent with the field data indicating that the mean catch of American eel leptocephali per unit effort in the Gulf Stream system increases dramatically northward from the Straits of Florida with the greatest concentrations occurring in the Canadian Maritime provinces and the American north Atlantic region 
from Maine to Virginia (Kleckner and McCleave 1982). Based on an ecosystems approach, American eel distribution could be represented by seven LME (Fig. 4). Ideally, each subpopulation would be comprised of at least three contingents (see next section) or subpopulation units reflecting plasticity in movement patterns observed in American eel.

\section{Adding movement patterns (contingents)}

The occurrence of several migratory groups characterized by different movement behaviour in continental waters has been reported for several Anguilla species (Tsukamoto and Arai 2001; Morrison et al. 2003; Jessop et al. 2004). After arrival at the coast, a portion of elvers establishes residency in estuarine or coastal habitats, another portion moves between freshwater and estuarine habitats (amphidromous) during the growth (yellow) phase, and another portion migrates upstream to spend the yellow phase in lake and river habitats (Haro and Krueger 1988; Jessop et al. 2002, 2006). Finer classifications of movement patterns have been presented (e.g., Jessop et al. 2002; Daverat et al. 2006; Thibault et al. 2007b) but for purposes of modelling population dynamics three categories would suffice: freshwater residents; brackish/saltwater residents; and, amphidromous (e.g., Morrison et al. 2003). Evidence from temperate latitudes indicates that demographic traits clearly change between freshwater and saltwater habitats at about $200 \mathrm{~km}$ from the ocean (Goodwin 1999); population density decreases rapidly (Smogor et al. 1995) and the occurrence of amphidromous eel becomes unlikely (Morrison et al. 2003). These behavioural groups have been termed ecophenotypes (Tsukamoto and Arai 2001) and contingents (Jessop et al. 2002, 2004; Morrison et al. 2003). Switching between environments has been mainly observed in the Canadian Maritime provinces (Medcof 1969; Jessop 1987; Jessop et al. 2006) and could be explained as a bet-hedging strategy where the negative effects of environmental variation on individual fitness are minimized by moving between freshwater and estuarine habitats (Jessop et al. 2006). Overall, habitat-switching (amphidromous) contingents are expected to exhibit lower length-at-age and weightat age than brackish residents (Thibault et al. 2007b) but higher than freshwater residents (Morrison et al. 2003) at temperate latitudes. Over-wintering in freshwater habitats with marine feeding migrations has been observed in Quebec and Nova Scotia (Medcof 1969; Jessop 1987; Thibault et al. 2007a). In addition, these movements are short $(\sim 10 \mathrm{~km})$ and cannot be placed in the same category as larval or silver eel migrations (Thibault et al. 2007b).

The relative abundance of these contingents in a given system and across the geographic range are unknown (Haro et al. 2000), but local studies reveal that $64 \%$ of silver eel from the East River on the Atlantic coast of Nova Scotia (Jessop et al. 2002) and $65 \%$ of yellow eel in the lower Hudson River estuary (Morrison et al. 2003) showed evidence of movement between freshwater and estuarine habitats as yellow eel. Jessop et al. (2006) found that $71 \%$ of yellow eel sampled in the East River, Nova Scotia, displayed non-switching history while $29 \%$ had a history of switching between fresh and salt waters after an initial migration into freshwater as elvers. Differences in individual size or sex seem to be poorly associated with a particular contingent (Thibault et al. 2007b); instead, migratory behaviour seems to be mostly influenced by population density and changes in environmental conditions within habitats or the ecosystem (Feunteun et al. 2003). We expect contingent frequencies to be primarily a function of the estuary-coastal/freshwater productivity ratio (e.g., Gross et al. 1988), drainage area, and distance from the spawning area.

Large differences in somatic growth between contingents are expected to affect the age structure and the productivity of subpopulations (see Morrison and Secor 2003). For example, female silver eel with estuarine residence exhibit significantly higher growth rates than freshwater resident females in Nova Scotia (Jessop et al. 2004). Thus, movement must be considered in population models of American eel (see also Jessop et al. 2002) to represent the relative demographic contributions of contingents within subpopulations and across latitudinal clines in other factors such as productivity, temperature, and the duration of the growth season.

A useful modelling framework

Using a matrix approach to describe a panmictic (or quasi-panmictic) model, the entire American eel life cycle could be represented by three stages using the standard demographic practice of only including 
(a)

\section{Sub-population dynamics}

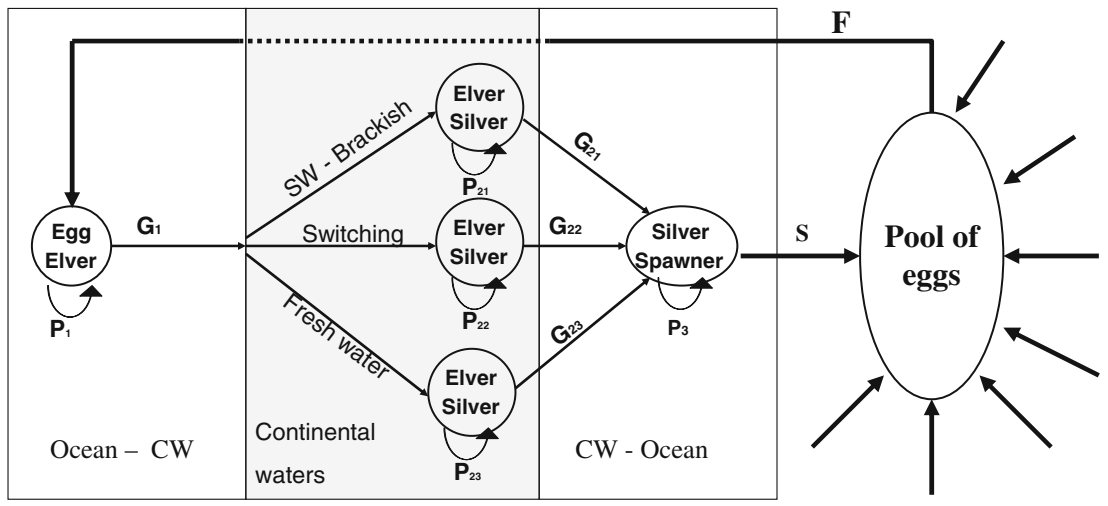

$\mathbf{M}_{K}=\left(\begin{array}{ccccccccc}\mathrm{P}_{1} & 0 & \mathrm{~F} & 0 & 0 & 0 & 0 & 0 & 0 \\ \mathrm{G}_{1} & \mathrm{P}_{21} & 0 & 0 & 0 & 0 & 0 & 0 & 0 \\ 0 & \mathrm{G}_{21} & \mathrm{P}_{31} & 0 & 0 & 0 & 0 & 0 & 0 \\ 0 & 0 & 0 & \mathrm{P}_{1} & 0 & \mathrm{~F} & 0 & 0 & 0 \\ 0 & 0 & 0 & \mathrm{G}_{1} & \mathrm{P}_{22} & 0 & 0 & 0 & 0 \\ 0 & 0 & 0 & 0 & \mathrm{G}_{22} & \mathrm{P}_{32} & 0 & 0 & 0 \\ 0 & 0 & 0 & 0 & 0 & 0 & \mathrm{P}_{1} & 0 & \mathrm{~F} \\ 0 & 0 & 0 & 0 & 0 & 0 & \mathrm{G}_{1} & \mathrm{P}_{23} & 0 \\ 0 & 0 & 0 & 0 & 0 & 0 & 0 & \mathrm{G}_{23} & \mathrm{P}_{33}\end{array}\right)$

(c)

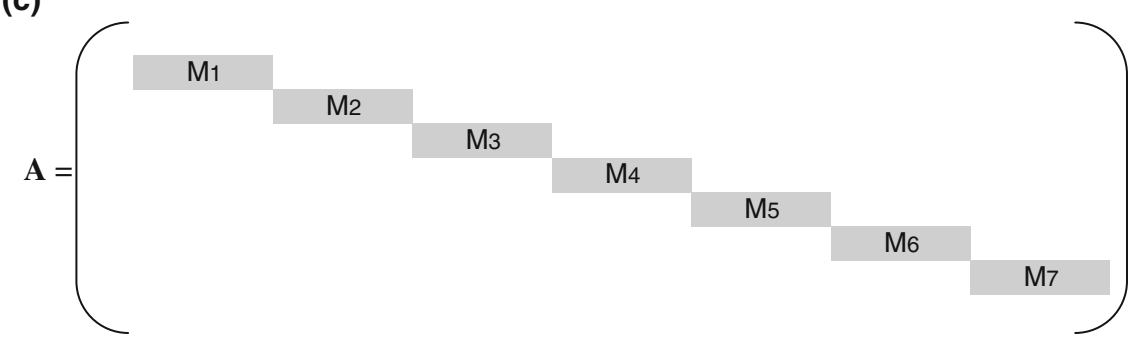

Fig. 5 Female demography to represent subpopulation dynamics of American eel represented by three life cycle stages (egg to elver, elver to silver, and silver to spawner) and three movement patterns representing different contingents (freshwater residence, switching between aquatic environments, and sea water (SW)-brackish residence). CW: continental waters. $G_{i j}$ is the probability of surviving stage $i$ and moving to $i+1$ for contingent $j$; $P_{i j}$ is the annual survival

female parameters (Fig. 5). First, an egg-to-elver stage starts in the Sargasso Sea, includes the first metamorphosis into glass eel, and finishes with the arrival of elvers to continental waters (in North America this part of the life cycle has an approximate duration of 1-1.5 years; COSEWIC 2006). Second, an elver-to-silver stage with varying durations for different subpopulations and contingents that includes the probability of stage $i$ for contingent $j$; $S$ is the reproductive contribution of the subpopulation; $F$ is the fecundity, which depends on the reproductive contribution of all subpopulations. (a) Schematic representation; (b) Matrix representation of subpopulation $K$. (c) Panmictic matrix population model for American eel. Each cell represents a subpopulation matrix as in $b$. The remaining matrix elements are zero as in the subpopulation matrices

second metamorphosis from yellow to silver eel and clear sexual differentiation and finishes with readiness to migrate back to the spawning area. Finally, a silverto-spawner stage that starts in continental waters, finishes with successful spawning at the Sargasso Sea, and has an approximate duration of 1-1.5 years (Castonguay et al. 1994a) depending primarily on migration distances. An extreme case is represented 
by silver eels migrating from western Lake Ontario, which must travel more than $4500 \mathrm{~km}$ to reach the spawning grounds (COSEWIC 2006).

The corresponding subpopulation matrix, therefore, will include survival and transition probabilities of the first stage (egg-to-elver) that are the same for each of the three contingents but survival and transition probabilities of the remaining two life cycle transitions that differ among contingents. Due to panmixis, a single value of annual fecundity will be representative of all subpopulations and contingents within subpopulations in a given year. What changes between subpopulations is the probability of surviving the transition from egg to elver, mainly influenced by distance to the spawning area, duration of passive drifting until arrival in continental waters, and the likelihood of occurrence. Therefore, the reproductive contribution of each subpopulation $\left(S_{i}\right)$ would be the sum of reproductive contributions from each contingent $\left(S_{i}=C_{i, 1}+C_{i, 2}+C_{i, 3}\right) ; \quad$ total fecundity $(F)$ would be the sum of reproductive contributions from all subpopulations $\left(F=\Sigma S_{i}\right)$. Population dynamics, represented as a demographic matrix, would then include as many cells as subpopulations are defined (seven populations using the LME approach; Fig. 5). A panmictic model with seven subpopulations based exclusively on female demography would have 84 matrix elements (see Fig. 5), many of which would need to be inferred from functional relationships derived from the available data and, perhaps, life history invariants (e.g., Beverton and Holt 1959; Charnov 1993).

Alternatively, to account for the existence of a conditional ESS and the resulting differences in life history between males and females, a two-sex model would need to include demographic characteristics of both sexes, with sex determination occurring during the transition from elver to silver (e.g., Fig. 6). Three individual matrices representing each contingent would form a subpopulation, and 7 subpopulations would represent the panmictic species (as in Fig. 5). Such a model, with 168 matrix elements, would be much more realistic than the previous model based solely on female demography.

The above biological modelling approach can be life-history based and constructed to represent unperturbed subpopulations. Under a quasi-panmictic scenario, the number of parameters for the female-based and two-sex models would change according to the

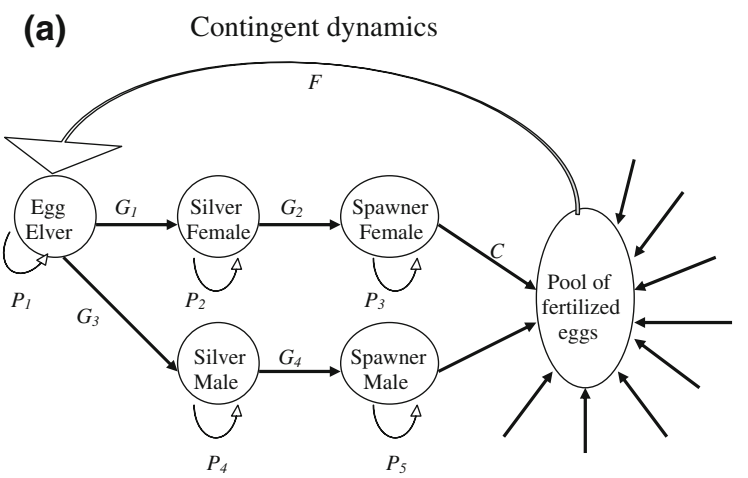

(b)

$$
\mathbf{N}_{L}=\left(\begin{array}{ccc|cc}
P_{1} & 0 & F & 0 & 0 \\
G_{1} & P_{2} & 0 & 0 & 0 \\
0 & G_{2} & P_{3} & 0 & 0 \\
\hline G_{3} & 0 & 0 & P_{4} & 0 \\
0 & 0 & 0 & G_{4} & P_{5}
\end{array}\right)
$$

Fig. 6 Two-sex demographic model of contingent dynamics of American eel represented with sex determination occurring in the transition from elver to silver. $G_{i j}, P_{i j}$, and $F$ as in Fig. 6 . $C$ is the reproductive contribution of a contingent within a subpopulation. $F$ is the fecundity, which depends on the reproductive contribution of all subpopulations. (a) Schematic representation; (b) Matrix representation of contingent $L$. The upper left submatrix describes the production of females and sexually undifferentiated elvers, the lower left submatrix the production of males, and the lower right submatrix the transition probabilities of males

number of subpopulations within genetically-defined populations. Nevertheless, the relevance of potential genetic segregation among subpopulations must be demographically significant to warrant the species' partition into more than one discrete unit.

Filling information gaps

Populating the models above would require the development and use of functional relationships relating subpopulation and contingent attributes with environmental or geographical factors. Life history attributes of fishes along latitudinal gradients indicate that, within a species, longevity increases and mortality decreases from south to north (Colby and Nepzy 1981; Beverton 1987; Braaten and Guy 2002), that body size increases from south to north (Winemiller 1991; Taylor and Gotelli 1994), and that growth rates (as indicated by the Von Bertalanffy growth coefficient $k$ ) increase from north to south (Beverton 1987; LobónCerbiá et al. 1996; Braaten and Guy 2002). Trade-offs between longevity and mortality produce differential 
growth patterns (Stearns and Crandall 1984) and sex ratios (Edeline 2007) across latitudinal gradients associated with productivity and temperature gradients. Observed patterns predict that eel males will be more prevalent in productive habitats with temperature regimes characterized by lower annual variation and higher degree-days favouring high rates of somatic growth during the early stages of the life cycle. Productivity gradients also vary substantially in rivers with higher productivity downstream (Vannote et al. 1980). Length and age, and the proportion of females increase with distance from the ocean at temperate latitudes (Martin et al. 1980; Goodwin 1999). These general patterns indicate that: (1) subpopulations in southern latitudes will be characterized by relatively shorter generation time and faster somatic growth than in northern latitudes; (2) contingents in coastal-estuarine waters will be characterized by relatively shorter generation times and faster somatic growth than in freshwater systems in northern latitudes (when located more than $50 \mathrm{~km}$ from the ocean); and, (3) an inverse pattern will be observed in southern latitudes. In addition, greater size and age of American eel leptocephali at arrival to the coast at extremes of the geographic range (Haro and Krueger 1988; Wang and Tzeng 1998) will enable longer inland migrations if needed and influence the propensity for a larger proportion of eel exhibiting freshwater residency.

Translating changes in somatic growth into fecundity can be accomplished with predictive equations based on body size (e.g. Wenner and Musick 1974; Barbin and McCleave 1997). These fecundity models could be extended to incorporate distance to the Sargasso Sea as increased migration distances decrease eel silver condition and diminish reproductive potential because eel do not feed during their oceanic spawning migration (Tesch 1977; Pankhurst and Sorensen 1984). Pre-collapse estimates of the reproductive contribution of American eel from the St. Lawrence River-Lake Ontario component based on a linear relationship between water discharge and recruitment and commercial landings (COSEWIC 2006) indicate that this region has contributed a substantial portion (27-67\%) of the total North American spawning output of American eel. This large contribution is explained by the size of the St. Lawrence watershed, which represents $19 \%$ of the freshwater runoff in the North American range (Verreault et al. 2004) and by the high fecundity of large female contingents in the upper St. Lawrence. Both criteria seem reasonable and, although a higher cost of migration (i.e., higher mortality) of silver eel migrants could be associated with longer distances from the spawning grounds, this cost could be offset by lower natural mortality associated with larger size. However, this approach does not consider that larger female size at maturity and seaward migration in the upper St. Lawrence not only translates into greater fecundity but also in longer generation times, thereby, reducing the annual frequency of silver eel from this contingent at the spawning grounds. Females in southern locations, although smaller and less fecund, are expected to exhibit shorter generation times and higher frequencies at the spawning grounds. Moreover, although the discharge method (COSEWIC 2006) assumed identical survivorship from recruitment to continental waters to return to the spawning grounds across all regions, and was applied exclusively to North American subpopulations, this approach could be improved by incorporating differences in life history traits (e.g., survival rates, somatic growth rates, sex ratio, age at maturity, age at seaward migration, fecundity) among subpopulations and contingents across the entire geographic range, not only North America.

The frequency of contingents vary with latitude (Daverat et al. 2006), with actual catadromy occurring most frequently in the tropics (McDowal 1987). The giant mottled eel, A. marmorata, whose distribution is limited to tropical latitudes, dwells almost exclusively in freshwater habitats during the growth phase, avoiding brackish waters (Shiao et al. 2003). These patterns are consistent with the prediction that the proportion of eel residing in marine and estuarine habitats increases with latitude and that a latitudinal threshold exists where the suitability of marine and freshwater habitats is similar. For example, Tzeng et al. (2003) found little difference in the proportions of A. japonica with different residence histories at $35^{\circ} \mathrm{N}$ latitude. The geographic position of a latitudinal threshold defining the frequency of American eel contingents would be an interaction between aquatic productivity and the size of leptocephali at arrival to coastal environments. Wang and Tzeng (1998) found that the midpoint for the occurrence of the smallest American eel leptocephali was located in North Carolina $\left(35^{\circ} \mathrm{N}\right)$, increasing towards southern (Haiti and Florida) and northern (New Brunswick and Nova Scotia) sites. 
Large amounts of recently collected and summarized American eel biological data (e.g., Van Den Avyle 1984; Facey and Van Den Avyle 1987; Goodwin 1999; ASMFC 2000; Anonymous 2001; COSEWIC 2006) could populate preliminary models. Functional relationships could infer life history traits for locations lacking data and uncertainty in parameter estimation associated with environmental and demographic stochasticity could be dealt with by bootstrap techniques and Monte Carlo simulations (see De Leo et al. 2009). Maximum likelihood functions could link available data with equations describing the underpinning ecological processes; nested models could be compared with log-likelihood tests, and model selection using information-theoretic models (e.g., Akaike Information Criterion; Burnham and Anderson 1998).

\section{Incorporation of perturbations in a global model}

\section{A posteriori input of anthropogenic factors}

Effective eel management requires knowledge and balancing of natural and human-related mortality rates at each life stage (Jessop 2000) in each subpopulation contingent and knowledge of the relative contribution of each subpopulation contingent to population fitness. Although latitudinal gradients (e.g., productivity and temperature) can exert stronger influences on life history than variation in stream habitat (Braaten and Guy 2002), anthropogenic perturbations may still alter life history parameters independently of the ecological processes represented by latitudinal gradients. Dams, exploitation, and hydropower turbines clearly constitute artificial selective pressures against freshwater yellow and silver eel, but the relative effects that reduced fish passage and anthropogenic mortality have on population dynamics of the entire species are qualitatively different. These selective pressures are proportional to the magnitude of these impacts. For example, commercial weirs can intercept up to $98 \%$ of silver eel migrating downstream (Kircheis 1999), dams exclude about $84 \%$ of suitable river and stream habitat along the east coast of North America and in eastern Lake Ontario (Busch et al. 1998), and turbine mortality can be 15-50\% or higher for large eel (Berg 1986; Montén 1985). As a result of semelparity, silver eel mortality not only eliminates a portion of the population but reduces the number of future potential spawners, with an overall reduction in recruitment (see also Edeline 2007). Reduced recruitment reduces densities and inland migration resulting from the ideal free distribution in temperate latitudes, but the proportion of freshwater residents would not be equally affected by reduced recruitment in tropical latitudes because the main driver of inland migration is not density per se but productivity, and large inland movements may be facilitated by larger larval size at arrival to the coast at extremes of the geographic range (see section "Size at arrival to the coast").

In temperate latitudes, density diminishes exponentially from the coast to freshwater systems (Smogor et al. 1995) and even faster when dams are present (White and Knights 1997; Machut et al. 2007). However, high densities can be recorded below barriers and other artificial structures known to inhibit upstream migration (Wiley et al. 2004). Blocking upstream passage is expected to reduce the relative frequency of freshwater residents, mostly females characterized by large body size, late age at maturity, and greater fecundity in temperate latitudes, and higher proportions of males characterized by small body size and early age at maturity in southern latitudes (Van Den Avyle 1984). Therefore, the main impact of dams will be a reduction in overall fecundity through reduced body size and reduced proportion of females. While barriers strongly influence the demographic characteristics of American eel contingents (Machut et al. 2007), they also slow invasion rates of the parasitic nematode Anguillicola crassus in tributaries (Machut 2006; see below in section "Additional causes of decline").

Ignoring panmixis (or quasi-panmixis) makes population modelling easier but provides a false perception that management decisions can be drawn based on subpopulation contingents. For example, greater somatic growth in North American estuaries has led some authors to conclude that estuaries could support higher fishing mortality than freshwater areas (e.g., Morrison and Secor 2003), and that harvest in estuaries only may be a defensible management policy (Anonymous 2001). Without knowing the demographic contribution of each subpopulation and contingent to the fitness and viability of the species, management decisions that ignore potential changes in sex ratio, fecundity, effective population size, and 
recruitment caused by fishing mortality concentrated on particular contingents is risky. Targeting areas of high productivity seems like a logical decision from an exploitation perspective but may be inconsistent with the conservation and long-term persistence of the species.

Gaps in our knowledge of American eel ecology have not prevented decisions against its protection under the US Endangered Species Act or prevented delays to protect this species under the Canadian Species at Risk Act. Despite declines and extirpations in parts of their historic range, the US Fish and Wildlife Service (USFWS) determined in 2007 that the tremendous adaptability, resilience, and geographic distribution of the species make it unlikely to go extinct, concluding that population declines are reversible (USFWS 2008). In Canada, consultations are still underway for consideration of American eel as a species at risk under federal and provincial legislation (DFO 2007). Poor knowledge of the implications that critical aspects of the life history of the species, such as panmixis, semelparity, and latitudinal gradients in sex ratios and reproductive potential, have on population dynamics and viability should advocate for a precautionary approach (see also MacGregor et al. 2008) and consideration of current declines and extirpations as valid reasons for protection in light of the uncertainties and paucity of data, particularly for southern subpopulations.

\section{Additional perturbation sources}

For species with large geographic distributions, there are few natural or human-induced processes that can simultaneously affect population dynamics across the entire range. Among the natural processes, oceanic changes in the Sargasso Sea and the spread of the infectious nematode A. crassus (Moser et al. 2001) seem to be causes of increasing concern. Large-scale perturbations in the Sargasso Sea have the potential to impact the entire American eel species as a result of disrupted reproductive success and reduced larval survival. There is abundant evidence that the North Atlantic Oscillation (NAO) is a dominant oceanicatmospheric phenomenon related to changes in the physical and biological structure of the North Atlantic, affecting a wide range of marine organisms from zooplankton to fishes (Weijerman et al. 2005). Significant negative correlations have been found between the NAO and long-term catches of A. anguilla, probably due to reduced larval survival attributed to warming of the spawning area, declining winds related to larval transport, and shallowing of the mixed layer depth where larvae feed (Friedland et al. 2003). Similarly, declining larval survival in A. japonica has been linked to El Niño and associated northward advance of salinity fronts (Kimura and Tsukamoto 2006). The distribution and dispersal of American eel along the North Atlantic coast depends directly on the strength and position of the Gulf Stream (Wirth and Bernatchez 2003), partly because most leptocephali enter the Gulf Stream directly from the Sargasso Sea rather than by a more southern route through the Bahamas (Kleckner and McCleave 1982). Climate change and the warming of the North Atlantic (Friedland et al. 2003) could be changing the position and strength of the Gulf Stream, thereby, altering the distribution of larvae and potentially reducing recruitment rates in the northern part of the geographical range (Castonguay et al. 1994b; Jessop 1998). Moreover, it is possible that northward movement of the spawning area can result in increased retention of leptocephali within the Sargasso Sea gyre reducing the number of larvae arriving to continental waters each year (Friedland et al. 2003). Only a global assessment would have the capacity to link these oceanographic phenomena with regional recruitment and population fitness.

The spread of the nematode A. crassus (Moser et al. 2001) is hypothesized to be one of the ecological factors driving the widespread decline in American eel abundances (Haro et al. 2000) as a result of reductions in growth (Thomas and Ollevier 1992) and swimming ability (Sprengel and Luchtenberg 1991). Both, reduced growth and swimming ability will adversely affect migrating silver eel given the positive relationship between eel size and infection rate (Moser et al. 2001), thus reducing or eliminating the reproductive contribution of infected individuals. Several studies have revealed that the prevalence and intensity of $A$. crassus in the swimbladder of $A$. rostrata are higher in freshwater than brackish-water habitats (Kirk et al. 2000; Moser et al. 2001; Morrison and Secor 2003). Although death by infection is uncommon, acute infection can lead to hemorrhagic lesions, swim bladder collapse, and decreased appetite, causing eventual death (Barse and Secor 1999). Quantitative information on growth 
and mortality changes linked to A. crassus infections and infection rates within contingents, mostly affecting eels in freshwater, could be used to infer the role of this factor on subpopulation dynamics and population performance.

Harvest in the Sargasso Sea

Insufficient life history information about the oceanic phases of American eel have precluded the identification and monitoring of the agents of population decline operating in the ocean. Knowledge of factors influencing mortality during the transition from egg to elver and additional information on the reproductive ecology of silver eel would assist our understanding and management of this critical part of the life cycle. Unfortunately, not only are American eel harvested at every life stage (glass, elver, yellow, and silver) but their spawning substrate, Sargassum spp., is commercially harvested as well (Stoner 1983). Although a survey of pelagic Sargassum in the North Atlantic Ocean, Caribbean Sea, and the Gulf of Mexico between 1977 and 1981 showed that the biomass of plants in this region was less than $6 \%$ of historic values (Stoner 1983), the quantity and distribution of Sargassum in the Sargasso Sea proper had not changed significantly (Butler et al. 1983). However, harvest of Sargassum in the Sargasso Sea began in 1987 , with approximately $75 \%$ of the total Sargassum harvested in the southern North Atlantic (SAFMC 1998) and presumably, there is no current Sargassum harvest (US Department of the Interior 2007). Notwithstanding, the magnitude of this anthropogenic perturbation on American eel is unknown and a fraction of leptocephali mortality could be associated with incidental harm caused by the commercial harvesting of Sargassum. New data could be incorporated into a panmictic (or quasi-panmictic) model to infer the effects of different levels of Sargassum harvest on American eel recruitment and abundance of different life stages in continental waters.

\section{Final remarks}

Incorporating local- and large-scale factors influencing American eel population dynamics to produce defensible predictions of population responses to anthropogenic and oceanic phenomena is possible only within a global framework. Any recovery strategy implemented at a regional level with only regional data will fail if large-scale natural or anthropogenic factors are at work. These agents can operate on several subpopulations simultaneously (e.g., large-scale oceanic phenomena) or impact individual subpopulation contingents with high demographic contributions to the species. Therefore, any regional initiative requires international cooperation to enact effective management strategies. The "management unit" specified in the US Fishery Management Plan for American eel regards panmixis as an important ecological process by incorporating all American eel subpopulations occurring in territorial seas and inland waters along the Atlantic coast from Maine to Florida (ASMFC 2000). However, given that factors affecting any subpopulation contingent have the potential to affect the population dynamics of the entire species, the large demographic contributions ascribed to Canadian subpopulations (COSEWIC 2006), and the paucity of data for southern subpopulations in the Caribbean, Central and South America, the creation of robust population models to guide effective management still require international collaboration (see also MacGregor et al. 2008). Understanding the complexity of interactions among ecological processes underpinning variation in occurrence and life history of American eel could be increased through modelling efforts combined with data collection across the entire geographic range. These data must include both biological information and estimates of human-derived perturbation rates (e.g., fishing mortality, number and type of barriers, implications for fish passage) to improve the realism of functional relationships representing important ecological processes and our ability to project realistic scenarios of population viability and management or recovery strategies.

Acknowledgments Thanks to T. Johnson, T. Pratt, N. Mandrak, and D. Cairns for comments on a previous version of the manuscript. This research was supported by funding from the DFO Species at Risk Program (SARCEP) and a Visiting Fellowship with the Great Lakes Laboratory for Fisheries and Aquatic Sciences to L. A. Vélez-Espino.

Open Access This article is distributed under the terms of the Creative Commons Attribution Noncommercial License which permits any noncommercial use, distribution, and reproduction in any medium, provided the original author(s) and source are credited. 


\section{References}

Anonymous (2001) Report of the EIFAC/ICES working group on eels. Advisory committee on fisheries management, international council for the exploration of the Sea. CM 2001/ASFM: 03

Arendt JD (1997) Adaptive intrinsic growth rates: an integration across taxa. Q Rev Biol 72:149-171

ASMFC (2000) Interstate fishery management plan for American eel. Fishery management report 36, United States Atlantic States marine fisheries commission

Avise JC, Felley J (1979) Population structure of freshwater fishes I. Genetic variation of bluegill (Lepomis macrochirus) populations in man-made reservoirs. Evolution 33: $15-26$

Avise JC, Helfman GS, Saunders NC, Hales LS (1986) Mitochondria DNA differentiation in North Atlantic eels: population genetic consequences of an unusual life history pattern. Proc Natl Acad Sci USA 83:4350-4354

Barbin GP, McCleave JD (1997) Fecundity of the American eel Anguilla rostrata at $45^{\circ} \mathrm{N}$ in Maine. USA J Fish Biol 51:840-847

Barse AM, Secor DH (1999) An exotic nematode parasite of the American eel. Fisheries 24:6-10

Beamesderfer RC, North JA (1995) Growth, natural mortality, and predicted response to fishing for largemouth bass and smallmouth bass populations in North America. N Am J Fish Manag 15:688-704

Benke AC, Hall CAS, Hawkins CP, Lowe-McConnell RH, Standford JE, Suberkropp K, Ward JV (1988) Bioenergetic considerations in the analysis of stream ecosystems. J N Am Benthol Soc 7:480-502

Berg R (1986) Fish passage through Kaplan turbines at a power plant on the River Neckar and subsequent eel injuries. Vie et Milieu 36:307-310

Beverton RJH (1987) Longevity in fish: some ecological and evolutionary considerations. In: Woodhead AD, Thompson KH (eds) Evolution of longevity in animals. Plenum, New York, pp 161-185

Beverton RJH, Holt SJ (1959) A review of the lifespans and mortality rates of fish in nature, and their relation to growth and other physiological characteristics. In: Wolstenholme GEW, O'Connor M (eds) The lifespan of animals. Ciba foundation colloquia on ageing, vol 5. J \& A Churchill Ltd, London

BII (2001) The decline of American eel (Anguilla rostrata) in the Lake Ontario/St. Lawrence River ecosystem: a modeling approach to identification of data gaps and research priorities. Prepared for GLFC, Ann Arbor, Michigan by Beak international incorporated, Brampton, Ontario. BII 21852.10

Boetius J (1985) Greenland eels, Anguilla rostrata LeSeur. Dana 4:41-48

Braaten PJ, Guy CS (2002) Life history attributes of fishes along the latitudinal gradient of the Missouri River. Trans Am Fish Soc 131:931-945

Burnham KP, Anderson DR (1998) Model selection and inference: a practical information-theoretic approach. Springer, New York

Busch WDN, Lary SJ, Castilione CM, McDonald RP (1998) Distribution and availability of Atlantic coast freshwater habitat for American eel (Anguilla rostrata). Administrative report 98-2. US Fish and Wildlife Service, Amherst

Butler JN, Morris BF, Cadwallader J, Stoner AW (1983) Studies of Sargassum and the Sargassum Community. Special publication no. 22, Bermuda Biological Station for Research

Casselman JM (2003) Dynamics of resources of the American eel, Anguilla rostrata: declining abundance in the 1990s. In: Aida K, Tsukamoto K, Yamauchi K (eds) Eel biology. Springer, Tokyo, pp 255-274

Castonguay M, Hodson PV, Couillard CM, Eckersley MJ, Dutil JD, Verreault G (1994a) Why is recruitment of the American eel, Anguilla rostrata, declining in the St. Lawrence River and Gulf? Can J Fish Aquat Sci 51:479-488

Castonguay M, Hodson PV, Moriarty C, Drinkwater KF, Jessop BM (1994b) Is there a role of the ocean environment in American and European eel decline? Fish Oceanog 3: 197-203

Caughley G (1994) Directions in conservation biology. J Anim Ecol 63:215-244

Charnov EL (1993) Life history invariants: some explorations of symmetry in evolutionary ecology. Oxford University Press, Oxford

Charnov EL, Bull J (1977) When is sex environmentally determined? Nature 266:828-830

Colby PJ, Nepzy SJ (1981) Variation among stocks of walleye (Stizostedium vitreum vitreum): management implications. Can J Fish Aquat Sci 38:1814-1831

Colombo G, Grandi G (1996) Histological study of the development and sex differentiation of the gonad in the European eel. J Fish Biol 48:493-512

Connover DO, Brown JJ, Ehtisham A (1997) Countergradient variation in growth of young stripped bass (Morone saxatilis) from different latitudes. Can J Fish Aquat Sci 54: 2401-2409

COSEWIC (2006) COSEWIC Assessment and status report on the American eel Anguilla rostrata in Canada. Committee on the status of endangered wildlife in Canada. Ottawa. $\mathrm{x}+71 \mathrm{pp}$. (www.sararegistry.gc.ca/status/status_e.cfm)

Daverat F, Tomás J (2006) Tactics and demographic attributes in the European eel Anguilla anguilla in the Gironde watershed, SW France. Mar Ecol Prog Ser 307: 247-257

Daverat F, Limburg KE, Thibault I, Shiao JC, Dodson JJ, Caron F, Tzeng WN, Iiizuka Y, Wickstrom H (2006) Phenotypic plasticity of habitat use by three temperate eel species Anguilla anguilla, A. japonica, and A. rostrata. Mar Ecol Prog Ser 308:231-241

Davey AJH, Jellyman DJ (2005) Sex determination in freshwater eels and management options for manipulation of sex. Rev Fish Biol Fish 15:37-52

De Leo GA, Gatto M (1996) Trends in vital rates of the European eel: evidence for density dependence? Ecol Appl 6:1281-1294

De Leo GA, Melià P, Gatto M, Crivelli AJ (2009) Eel population modeling and its application to conservation management. In: Casselman JM, Cairns DK (eds) Eels at the edge: science, status, and conservation concerns. Proceedings of the 2003 international eel symposium. 
American Fisheries Society symposium publication 58, Bethesda, Maryland, pp 327-345

Dekker W (2003) Did lack of spawners cause the collapse of the European eel, Anguilla anguilla? Fish Manag Ecol 10:365-376

DFO (2007) American eel management plan. Available: www.dfo-mpo.gc.ca/comunic/fish_man/consultations/eelanguille_e.htm

Dolan JA, Power G (1977) Sex ratio of American eels, Anguilla rostrata, from the Matamek River systems, Quebec, with remarks on problems in sex identification. J Fish Res Board Can 34:294-299

Duda AM, Sherman K (2002) A new imperative for improving management of large marine ecosystems. Ocean Coast Manag 45:797-833

Edeline E (2007) Adaptive phenotypic plasticity of eel diadromy. Mar Ecol Prog Ser 341:229-232

Edeline E, Dufour S, Elie P (2005) Role of glass eel salinity preference in the control of habitat selection and growth plasticity in Anguilla anguilla. Mar Ecol Prog Ser 304: 191-199

EPRI (1999) American eel (Anguilla rostrata) scooping study: a literature review of life history, stock status, population dynamics, and hydroelectric impacts. Electric Power Research Institute, TR-I 1873. Palo Alto, California

Facey DE, Helfman GS (1985) Reproductive migrations of American eels in Georgia. Proc Annu Conf Southeast Assoc Fish Wildl Agencies 39:132-138

Facey DE, Van Den Avyle MJ (1987) Species profiles: life histories and environmental requirements of coastal fishes and invertebrates (North Atlantic)_American eel. US Fish Wildl. Serv. Biol. Rep. 82(11.74). US Army Corps of Engineers, TR EL-82-4

FAO (1996) Precautionary approach to capture fisheries and species introductions. FAO technical guidelines for responsible fisheries 2 , Rome

FAO (2002) The living marine resources of the western central Atlantic. Volume 2: bony fishes part 1 (Acipenseridae to Grammatidae). FAO species identification guide for fishery purposes and American Society of ichthyologists and herpetologists special publication no. 5, Rome

Feunteun E (2002) Management and restoration of European eel population (Anguilla anguilla): an impossible bargain. Ecol Eng 18:575-591

Feunteun E, Accou A, Guillouet J, Laffaille P, Legault A (1998) Spatial distribution of an eel population (Anguilla anguilla L.) in a small coastal catchment of northern Brittany (France). Consequences of hydraulic works. Bulletin Francais de la Peche et de la Piscicultura 349: 129-139

Feunteun E, Laffaille P, Robinet T, Briand C, Baisez A, Olivier JM, Acou A (2003) A review of upstream migration and movements in inland waters by anguillid eels: toward a general theory. In: Aida K, Tsukamoto K, Yamauchi K (eds) Eel biology. Springer, Tokio, pp 191-212

Fournier D, Caron F (2005) Travaux de recherche sur l'anguille d'Amerique (Anguilla rostrata) de la Petite Riviere de la Trinité en 2001 et synthese des travaux de 1999 a 2001. Ministere des Ressources Naturelles et de la Faune, Direction de la Recherche sur la Faune
Fretwell SD, Lucas HL (1970) On territorial behavior and other factors influencing habitat distribution in birds. Acta Biotheor 19:16-36

Friedland KD, Miller MJ, Knights B (2003) Oceanic changes in the Sargasso Sea and declines in recruitment of the European eel. ICES J Mar Sci 64:519-530

Gagnon M (2002) Étude des caractérisques biophysiques, des usages et du potentiel myicole de six barachois du sud de la Gaspésie. Parts I and II. Biorex Inc. Report presented to the Societé de Developpement de l'Industrie Maricole (SODIM), Quebec

Goodwin KR (1999) American eel subpopulation characteristics in the Potomac River drainage, Virginia. MSc thesis, Virginia Polytechnic Institute and State University, Virginia

Gray RW, Andrews CW (1971) Age and growth of the American eel (Anguilla rostrata, LeSeur) in Newfoundland waters. Can J Zool 49:121-128

Gross MR (1996) Alternative reproductive strategies and tactics: diversity within sexes. Trends Ecol Evol 11(2):92-98

Gross MR, Coleman RM, McDowal RM (1988) Aquatic productivity and the evolution of diadromous fish migration. Science 239:1291-1293

Guisan A, Zimmermann N (2000) Predictive habitat distribution models in ecology. Ecol Model 135:147-186

Hansen RA, Eversole AG (1984) Age, growth and sex ratio of American eels in brackish-water portions of a South Carolina river. Trans Am Fish Soc 113:744-749

Haro AJ, Krueger WH (1988) Pigmentation, size and migration of elvers (Anguilla rostrata (LeSueur)) in a costal Rhode Island stream. Can J Zool 66:2528-2533

Haro A, Richkus W, Whalen K, Hoar A, Busch WD, Lary S, Brush T, Dixon D (2000) Population decline of the American eel: implications for research and management. Fisheries 25(9):7-16

Harrel RM, Locayano HH (1982) Age, growth and sex ratio of American eel in the Cooper River, South Carolina. Proc Ann Conf SE Assoc Fish Wildl Agencies 34:349-359

Helfman GS, Bozeman EL, Brothers EB (1984) Size, age, and sex of American eels in a Georgia River. Trans Am Fish Soc 113:132-141

Helfman GS, Facey DE, Stanton Hales L, Bozeman EL (1987) Reproductive ecology of the American eel. Am Fish Soc Symp 1:42-56

Helfman GS, Collette BB, Facey DE (1997) The diversity of fishes. Blackwell Science, Malden

Holmgren K (1996) Effect of water temperature and growth variation on the sex ratio of experimentally reared eels. Ecol Freshw Fish 5:203-212

Holmgren K, Mosegaard H (1996) Implications of individual growth status on future sex of the European eel. J Fish Biol 49:910-925

Holmgren K, Wickstrom H, Clevestam P (1997) Sex-related growth of European eel, Anguilla anguilla, with focus on median silver eel age. Can J Fish Aquat Sci 54:2775-2781

Huish MT, Pardue GB (1978) Ecological studies of one channelized and two unchannelized wooded coastal swamp streams in North Carolina. US Fish and Wildlife Service, FWZ/OBS-78/85

Hurley DA (1972) The American eel (Anguilla rostrata) in eastern Lake Ontario. J Fish Res Board Can 29:535-543 
Ibbotson A, Smith J, Scarlett P, Aprahamian MW (2002) Colonisation of freshwater habitats by the European eel Anguilla anguilla. Freshw Biol 47:1696-1706

Iliffe TM (1993) Fauna troglobia acuática de la Península de Yucatán. In: Salazar SI, González NE (eds) Biodiversidad Marina y Costera de México. Cpm. Nal. Biodiversidad y CIQRO, México, pp 373-386

Jellyman D (2001) The influence of growth rate on the size of migrating female eels in Lake Ellesmere, New Zealand. J Fish Biol 58:725-736

Jessop BM (1987) Migrating American eels in Nova Scotia. Trans Am Fish Soc 116:161-170

Jessop BM (1998) The management of, and fishery for, American eel elvers in the Maritime Provinces, Canada. Bull Fr Péche Piscic 349:103-116

Jessop BM (2000) Estimates of population size and instream mortality rate of American eel elvers in a Nova Scotia River. Trans Am Fish Soc 129:514-526

Jessop BM, Shiao JC, Iiizuka Y, Tzeng WN (2002) Migratory behaviour and habitat use by American eels Anguilla rostrata as revealed by otolith microchemistry. Mar Ecol Prog Ser 233:217-229

Jessop BM, Shiao JC, Iiizuka Y, Tzeng WN (2004) Variation in the annual growth, by sex and migration history, of silver American eels Anguilla rostrata. Mar Ecol Prog Ser 272:231-244

Jessop BM, Shiao JC, Iiizuka Y, Tzeng WN (2006) Migration of juvenile American eels Anguilla rostrata between freshwater and estuary, as revealed by otolith microchemistry. Mar Ecol Prog Ser 310:219-233

Jonsson B, Jonsson N (1993) Partial migration: niche shift versus sexual maturation in fishes. Rev Fish Biol Fish 3: 348-365

Kaschner K, Ready J, Agbayani E, Eastwood P, Rees T, Reyes K, Rius J, Froese R (2007) About AquaMaps: creating standardized range maps of marine species. http://fishbase. sinica.edu.tw/tools/aquamaps/. (Version of May 2007)

Kimura S, Tsukamoto K (2006) The salinity front in the North Equatorial Current: a landmark for the spawning migration of the Japanese eel (Anguilla japonica) related to the stock recruitment. Deep-Sea Res II 53:315-325

Kircheis FW (1999) Status of ell weir research in Maine: 1998 season. Eel and elver progress report, May 1999. Stock enhancement division. Maine Department of Marine Resources, Augusta

Kirk RS, Kennedy CR, Lewis JW (2000) Effect of salinity on hatching, survival, and infectivity of Anguillicola crassus (Nematoda: Dranculoidea) larvae. Dis Aquat Org 40:211-218

Kleckner RC, McCleave JD (1982) Entry of migrating American eel leptocephali into the Gulf stream system. Helgolander Meeresuntersuchungen 35:329-339

Kleckner RC, McCleave JD (1985) Spatial and temporal distribution of American eel larvae in relation to North Atlantic Ocean current systems. Dana 4:67-92

Knights B (2003) A review of the possible impacts of longterm oceanic and climate changes and fishing mortality on recruitment of anguillid eels of the Northern Hemisphere. Sci Total Environ 310:237-244

Krueger WH, Oliveira K (1997) Sex, size, and gonad morphology of silver American eels, Anguilla rostrata. Copeia 2:415-420
Krueger WH, Oliveira K (1999) Evidence for environmental sex determination in the American eel, Anguilla rostrata. Environ Biol Fish 55:381-389

Laffaille P, Feunteun E, Baisez A, Robinet T, Acou A, Legault A, Lek S (2003) Spatial organisation of European eel (Anguilla anguilla) in a small catchment. Ecol Freshw Fish 12:254-264

Lamson HM, Shiao JC, Iizuka Y, Tzeng WN, Cairns DK (2006) Movement patterns of American eels (Anguilla rostrata) between salt- and freshwater in a coastal watershed, based on otolith microchemistry. Mar Biol 149:1567-1576

Lobón-Cerbiá J, Dgebuadze C, Utrilla G, Rincón PA, GrandoLorencio C (1996) The reproductive tactics of dace in central Siberia: evidence for temperature regulation of the spatio-temporal variability of its life history. J Fish Biol 48: 1074-1087

Lowe-McConnell RH (1987) Ecological studies in tropical fish communities. Cambridge University Press, Cambridge

MacGregor R, Mathers A, Thompson P, Casselman JM, Dettmers JM, LaPan S, Pratt TC, Allen B (2008) Declines of American eel in North America: complexities associated with bi-national management. International Governance of Fisheries Ecosystems. American Fisheries Society, pp 357-381

Machut LS (2006) Population dynamics, Anguillicola crassus infection, and feeding selectivity of American eel (Anguilla rostrata) in tributaries of the Hudson River, Hew York. MSc thesis, SUNY College of Environmental Science and Forestry, Syracuse

Machut LS, Limburg KE, Schmidt RE, Dittman D (2007) Anthropogenic impacts on American eel demographics in Hudson River tributaries, New York. Trans Am Fish Soc 136:1699-1713

Martin DB, Novotny JF, O’Bryan GK (1980) Limnology of four Missouri reservoirs. Part I: physiochemistry and phytoplankton production. Proc South Dakota Acad Sci 59:91-114

McCleave JD (1993) Physical and behavioral controls on the oceanic distribution of leptocephali. J Fish Biol 43: 243-273

McDowal RM (1987) Evolution and importance of diadromy, the occurrence and distribution of diadromy among fishes. Am Fish Soc Symp 1:1-13

Medcof JC (1969) Fishermen's reports of freshwater and saltwater migrations of Nova Scotia eels (Anguilla rostrata). Can Field Nat 83:132-138

Mittwoch U (1996) Sex-determining mechanisms in animals. Trends Ecol Evol 11(2):63-67

Montén E (1985) Fish and turbines: fish injuries during passage through power station turbines. Vattenfall, Stockholm

Moriarty C (1987) Factors influencing recruitment of the Atlantic species of anguillid eels. In: Dadswell MJ, Clauda RJ, Moffitt CM, Saunders RL, Rulifson RA, Cooper JE (eds) Common strategies of anadromous and catadromous fishes. American Fisheries Society, Symposium 1, Bethesda, pp 483-491

Moriarty C, Dekker W (1997) Management of the European eel. Mar Inst Fish Bull 15, Dublin

Morris DW (1987) Ecological scale and habitat use. Ecology 68:362-369

Morrison WE, Secor DH (2003) Demographic attributes of yellow-phase American eels (Anguilla rostrata) in the 
Hudson River estuary. Can J Fish Aquat Sci 60:14871501

Morrison WE, Secor DH, Piccoli PM (2003) Estuarine habitat use by Hudson River American eels as determined by otolith strontium:calcium ratios. In: Dixon DA (ed) Biology, management, and protection of catadromous eels. Am Fish Soc Symp 33:87-100

Moser ML, Patrick WS, Crutchfield JU (2001) Infection of American eels, Anguilla rostrata, by an introduced nematode parasite, Anguillicola crassus, in North Carolina. Copeia 3:848-853

Naismith IA, Knights B (1990) Modeling of unexploited and exploited populations of eels, Anguilla anguilla (L.), in the Thames estuary. J Fish Biol 37:975-986

Nunney L (1993) The influence of mating system and overlapping generations on effective population size. Evolution 47:1329-1341

Oliveira K (1999) Life history characteristics and strategies of the American eel, Anguilla rostrata. Can J Fish Aquat Sci 56:795-802

Oliveira K, McCleave JD (2000) Variation in population and life history traits of the American eel, Anguilla rostrata, in four rivers in Maine. Env Biol Fish 59:141-151

Oliveira K, McCleave JD (2002) Sexually different growth histories of the American eel in four rivers of Maine. Trans Am Fish Soc 131:203-211

Oliveira K, McCleave JD, Wipplehauser GS (2001) Regional variation and the effects of lake:river area on sex distribution of American eels. J Fish Biol 58:943-952

Pankhurst NW, Sorensen PW (1984) Degeneration of the alimentary tract in sexually maturing European Anguilla anguilla (L.) and American eels Anguilla rostrata (LeSeur). Can J Zool 62:1143-1149

Paulovits G, Viró P (1986) Age determination and growth of eel, Anguilla anguilla (L.) in Lake Ferto, Hungary. Fish Res 4:101-110

Pauly D (1980) On the interrelationships between natural mortality, growth parameters, and mean environmental temperature in 175 fish stocks. Journal du Conseil, Conseil International pour l'Exploration de la Mer 39:175-192

Penczak T, Lasso C (1991) Problems of estimating population parameters and production of fish in a tropical rain forest stream, North Venezuela. Hydrobiologia 215:121-133

Poole WR, Reynolds JD (1996) Age and growth of yellow Anguilla anguilla (L.) determined by two different methods. Ecol Freshw Fish 5:86-95

Randall RG, Kelso JRM, Minns CK (1995) Fish production in freshwaters: are rivers more productive than lakes? Can J Fish Aquat Sci 52:631-643

Richards LJ, Maguire J (1998) Recent international agreements and the precautionary approach: new directions for fisheries management science. Can J Fish Aquat Sci 55:15451552

Richkus WA, Whalen K (2000) Evidence for a decline in the abundance of the American eel, Anguilla rostrata (LeSeur), in North America since the early 1980s. Dana 12: 83-97

Russell IC, Potter ECE (2003) Implications of the precautionary approach for the management of the European eel, Anguilla anguilla. Fish Manag Ecol 10:395-401
SAFMC (1998) Final fishery management plan for pelagic Sargassum habitat of the South Atlantic region. South Atlantic fishery management council, Charleston

Servidio NL (1986) Gonad development in yellow phase American eels, Anguilla rostrata. M. Sc. Thesis, University of Rhode Island, Kingston

Sherman K (1994) Sustainability, biomass yields, and health of coastal ecosystems: an ecological perspective. Mar Ecol Prog Ser 112:277-301

Sherman K, Duda AM (1999) An ecosystem approach to global assessment and management of coastal waters. Mar Ecol Prog Ser 190:271-287

Shiao JC, lizuka Y, Chang CW, Tzeng WN (2003) Disparities in habitat use and migratory behavior between tropical eel Anguilla marmorata and temperate eel $A$. japonica in four Taiwanese rivers. Mar Ecol Prog Ser 261:233-242

Smogor RA, Angermeier PL, Gaylord CK (1995) Distribution and abundance of American eels in Virginia streams: tests of null models across spatial scales. Trans Am Fish Soc 124:789-803

Sogard SM (1997) Size-selective mortality in the juvenile stage of teleost fishes: a review. Bull Mar Sci 60:1129-1157

Sprengel G, Luchtenberg H (1991) Infection by endoparasites reduces maximum swimming speed of European smelt, Osmerus eperlanus, and European eel, Anguilla anguilla. Dis Aquat Org 11:31-35

Stearns SC, Crandall RE (1984) Plasticity for age and size at sexual maturity: a life-history response to unavoidable stress. In: Potts GW, Wootton RJ (eds) Fish reproduction: strategies and tactics. Academic Press, London, pp 13-33

Stone R (2003) Freshwater eels are slip-sliding away. Science 302:221-222

Stoner AW (1983) Pelagic Sargassum: Evidence for a major decrease in biomass. Deep-Sea Res A 30(4):469-474

Sullivan MC, Able KW, Hare JA, Walsh HJ (2006) Anguilla rostrata glass eel ingress into two, US east coast estuaries: patterns, processes and implications for adult abundance. $\mathrm{J}$ Fish Biol 69:1081-1101

Tatsukawa K, Matsumiya A (1999) Conservation and management of eel stocks in Japan. Gekkan Kaiyo, Gougai 18:1-8

Taylor CM, Gotelli NJ (1994) The macroecology of Cyprinella: correlates of phylogeny, body size, and geographic range. Am Nat 144:549-569

Tesch FW (1977) The eel: biology and management of Anguillid eels. Chapman and Hall, London

Tesch FW (2003) The eel. Blacwel Science, Oxford

Thibault I, Dodson JJ, Caron F (2007a) Yellow stage American eel movements determined by microtagging and acoustic telemetry in the St. Jean River watershed, Gaspé (Quebec, Canada). J Fish Biol 71:1095-1112

Thibault I, Dodson JJ, Caron F, Tzeng WN, Iizuka Y, Shiao JC (2007b) Facultative catadromy in American eels: testing the conditional strategy hypothesis. Mar Ecol Prog Ser 344:219-229

Thomas K, Ollevier F (1992) Paratenic hosts of the swimbladder nematode Anguillicola crassus. Dis Aquat Org 13:165-174

Tsukamoto K, Arai T (2001) Facultative catadromy of the eel Anguilla japonica between freshwater and seawater habitats. Mar Ecol Prog Ser 220:265-276 
Tsukamoto K, Aoyama J, Miller MJ (2002) Migration, speciation, and the evolution of diadromy in anguillid eels. Can J Fish Aquat Sci 59:1989-1998

Tzeng WN, Iizuka Y, Shiao JC, Yamada Y, Oka HP (2003) Identification and growth rates comparison of divergent migratory contingents of Japanese eel (Anguilla japonica). Aquaculture 216:77-86

US Department of the Interior (2007) 12 month finding on a petition to list the American eel as Threatened or Endangered. Fed Regist 72(22):4967-4997

USFWS (2008) The American eel. www.fws.gov/northeast/ ameel. Last visit: March 2008

Van Den Avyle MJ (1984) Species profiles: life histories and environmental requirements of coastal fishes and invertebrates (South Atlantic)_American eel. US Fish Wildl. Serv. FWS/OBS-82/11.24. US Army Corps of Engineers, TR EL-82-4

van Ginneken V, Vianen G, Muusze B, Palstra A, Verschoor L, Lugten O, Onderwater M, van Schie S, Niemantsverdriet P, van Heeswijk R, Eding E, van den Thillart G (2005) Gonad development and spawning behavior of artificially matured European eel (Anguilla anguilla L.). Anim Biol 55:203-218

Vannote R, Minshall GW, Cummins KW, Sedell JR, Cushing CE (1980) The river continuum concept. Can J Fish Aquat Sci 37:130-137

Verreault G, Pettigrew P, Tardif R, Pouliot G (2003) The exploitation of the migrating silver American eel in the St. Lawrence River Estuary, Quebec, Canada. In: Dixon DA (ed) Biology, management and protection of catadromous eels. American Fisheries Society, Symposium 33. Bethesda, Maryland, pp 225-234

Verreault G, Dumont P, Mailhot Y (2004) Habitat losses and anthropogenic barriers as a cause of population decline for American eel (Anguilla rostrata) in the St. Lawrence watershed, Canada. ICES CM 2004/S:04. 2004 ICES Annual Science Conference, Vigo, Spain

Vladykov VD (1966) Remarks on American eel (Anguilla rostrata LeSeur). Sizes of elvers entering streams; the relative abundance of adult males and females; present economic importance of eels in North America. Verh Int Verein Limnol 16:1007-1017

Vollestad LA (1992) Geographic variation in age and length at metamorphosis of maturing European eel: environmental effects and phenotypic plasticity. J Anim Ecol 61:41-48
Vollestad LA, Jonsson B (1988) A 13-year study of the population dynamics and growth of the European eel Anguilla anguilla in a Norwegian river: evidence for densitydependent mortality, and development of a model predicting yield. J Anim Ecol 57:983-997

Walsh PJ, Foster GD, Moon TW (1983) The effects of temperature on metabolism of the American eel Anguilla rostrata (LeSeur): compensation in the summer and torpor in the winter. Physiol Zool 56:532-540

Wang CH, Tzeng WN (1998) Interpretation of geographic variation in size of American eel Anguilla rostrata elvers on the Atlantic coast of North America using their life history and otolith ageing. Mar Ecol Prog Ser 168:35-43

Ware DM (1982) Power and evolutionary fitness of teleosts. Can J Fish Aquat Sci 39:3-13

Weijerman M, Lindeboom H, Zuur AF (2005) Regime shifts in marine ecosystems of the North Sea and Wadden Sea. Mar Ecol Prog Ser 298:21-39

Wenner CA, Musick JA (1974) Fecundity and gonad observations of the American eel, Anguilla rostrata, migrating from Chesapeake Bay, Virginia. J Fish Res Board Can 31:1387-1391

White EM, Knights B (1997) Dynamics of upstream migration of the European eel, Anguilla anguilla (L.), in the rivers Severn and Avon, England, with special reference to the effects of man-made barriers. Fish Manag Ecol 4:311-324

Wiley DJ, Morgan RP II, Hilderbrand RH, Raesly RL, Shumway DL (2004) Relations between physical habitat and American eel abundance in five river basins in Maryland. Trans Am Fish Soc 133:515-526

Williams GC, Koen RK (1984) Population genetics of North American catadromous eel (Anguilla). In: Turner BJ (ed) Evol Gen Fish Plenum, New York, pp 529-569

Winemiller KO (1991) Ecomorphological diversification in lowland freshwater fish assemblages from five biotic regions. Ecol Monogr 61:343-365

Winn HE, Richkus WA, Winn LK (1975) Sexual dimorphism and natural movements of the American eel (Anguilla rostrata) in Rhode Island streams and estuaries. Helgolander Wissenschaftliche Meeresuntersuchungen 27: 156-166

Wirth T, Bernatchez L (2003) Decline of North Atlantic eels: a fatal synergy? Proc R Soc Lond B 270:681-688

Wootton RJ (1992) Constraints in the evolution of fish life histories. Neth J Zool 42:291-303 